\title{
AUTONOMIA FORAL Y COMPETENCIAS SOBRE ADMINISTRACION MUNICIPAL EN NAVARRA*
}

\author{
POR \\ DEMETRIO LOPERENA ROTA \\ Profesor de Derecho Administrativo \\ de la Universidad del País Vasco
}

SUMARIO: I. AproXIMACIÓN Histórica: A) Evolución durante el siglo XIX. B) La revisión del Régimen Local de Navarra en 1925. - II. LA CONSTITUCION Y EL REGIMEN FORAL: A) Alcance de la Disposición adicional primera de la Constitución. B) El acceso de Navarra a la autonomía. - III. LAS COMPETENCIAS de NAVARRA SOBRE REGIMEN LoCAL: EL ARTICUlo 46 del Amejoramiento: A) El deslinde competencial. B) El Tribunal Administrativo de Navarra. C) La autonomía municipal en Navarra y en el Régimen general.IV. Ante la Ley foral de Administracion municipal.

\section{APROXIMACION HISTORICA}

La doctrina iuspublicista no ha sido muy tendente en el pasado a estudiar los regímenes especiales que coexistían con el común uniforme en el ámbito de la Administración Local. Ello ha originado un desconocimiento general del verdadero alcance de tales especialidades, al menos en el caso de Navarra. Este alcance incluso era desconocido también dentro de las lindes del Viejo Reino, ya que ha sido habitual en los juristas navarros envolver nuestro Régimen Foral en una densa niebla de apologético panforalismo, lo cual dificulta enormemente la búsqueda de los verdaderos perfiles jurídicos de un régimen especial que, como se verá, tiene un contenido nada despreciable.

\section{A) Evolución durante el siglo XIX}

Como se recordará, la incorporación de Navarra a la unidad constitucional se produjo en virtud de la Ley de Fueros de 25 de octubre de 1839, consecuencia directa del «abrazo de Vergara», que puso fin a la Primera Guerra Carlista en esta parte del Estado (1). En tal Ley se disponía:

* El presente trabajo es mi ponencia presentada a las aJornadas sobre Administración Locals, celebradas en Pamplona en enero de 1989. Varios de sus epígrafes coinciden con temas tratados en mi libro Derecho histórico y Régimen Local de Navarra, Pamplona, 1988. constituyendo una exposición sintética.

(1) Véase M. C. Mina Apat: Fueros y Revolución liberal en Navarra, Madrid, 1981; y R. Rodriguez Garraza: Navarra de Reino a provincia (1828-1841), Madrid, 1968. 
«Artículo 1. Se confirman los Fueros de las Provincias Vascongadas y Navarra sin perjuicio de la unidad constitucional de la monarquía.

Art. 2.9 El Gobierno tan pronto como la oportunidad to permita, y oyendo antes a las Provincias Vascongadas y a Navarra, propondrá la modificación indispensable que en los mencionados fueros reclame el interés de los mismos, conciliándolo con el general de la Nación y de la Constitución de la Monarquía, resolviendo entre tanto provisionalmente, y en la forma y sentido expresados, las dudas y dificultades que puedan ofrecerse, dando de ello cuenta a las Cortes.»

Una sencilla lectura de este texto nos indica que Navarra queda sometida a la unidad constitucional, cuyo contenido habrá de ser determinado mediante un deslinde competencial que se producirá tras cumplimentar un trámite de audiencia. Transitoriamente queda vigente el ordenamiento anterior (Fueros), y la resolución de los eventuales conflictos que pudieran producirse se remiten al Gobierno.

En efecto, así se hizo, y tras negociar políticamente con los representantes de Navarra con resultado exitoso, pues se llegó a un acuerdo, el Gobierno remitió un proyecto de ley a las Cortes Generales para definir con rango normativo suficiente cuáles eran las áreas competenciales que por ser inherentes a la unidad constitucional habían de reservarse las Instituciones centrales y qué otras podían continuar siendo de titularidad navarra. Este régimen autonómico que se consagra en la Ley de 16 de agosto de 1841 es el denominado Régimen Foral (2).

De la lectura de los 16 artículos de este «Estatuto Foral» no cabe concluir que el ámbito propio de la normativa autónoma resultase amplio, ni que la técnica utilizada para el deslinde competencial fuese depurada. No podía ser de otro modo en un Estado en el que la uniformidad era uno de los instrumentos con los que se pretendía conseguir la igualdad, y en el que los recursos de la técnica iuspublicista eran todavía casi inexistentes.

Un apartado de lo que suele entenderse como Régimen Local queda reservado en la Ley citada a las Instituciones de Navarra. Los artículos de la Ley que afectan al mismo son los siguientes:

«Art. 5. Los Ayuntamientos se elegirán y organizarán por las reglas generales que rigen o se adopten en lo sucesivo para toda la Nación.

Art. 6.․ Las atribuciones de los Ayuntamientos, relativas a la administración económica interior de los fondos, derechos y propiedades de los pueblos, se ejercerán bajo la dependencia

(2) Véase J. I. oel Burgo: Origen y fundamento del Régimen Foral de Navarra, Pamplona, 1968. 
de la Diputación provincial, con arreglo a su legislación especial.

Art. 7.o En todas las demás atribuciones los Ayuntamientos estarán sujetos a la Ley general.

Art. 10. La Diputación provincial, en cuanto a la administración de productos de los Propios, ventas, efectos vecinales, arbitrios y propiedades de los pueblos $y$ de la provincia, tendrá las mismas facultades que ejercían el Congreso de Navarra y la Diputación del Reino, y además las que siendo compatibles con éstas, tengan o tuviesen las otras Diputaciones provinciales de la Monarquía.»

La aproximación al contenido de esta Ley en su apartado del Régimen Local no puede hacerse desde una perspectiva metodológica análoga a la que utilizaríamos para interpretar un texto normativo actual y ello porque la dilatación en el tiempo de su vigencia convierte al método histórico en preponderante sobre cualquier otro que quiera utilizarse. Se trata, en definitiva, de averiguar los perfiles de la distribución competencial según los han interpretado las Instituciones públicas.

A este respecto debe recordarse que el ambiente políticoadministrativo del conjunto del Estado durante todo el siglo XIX fue muy desapacible. Asi, se sucedieron Constituciones progresistas y moderadas en razón de los vaivenes políticos; también las leyes de Régimen Local se sucedían con el mismo motivo, llegando a consagrarse como emblemáticas la Instrucción de 3 de febrero de 1823 para los liberales y la Ley de 14 de julio de 1840 para los moderados. Habrá que esperar a la Restauración para que se consolide el régimen jurídico de los Ayuntamientos y comience de verdad a atisbarse algún extremo de racionalidad y de eficacia en la actividad de la mayoría de las Administraciones públicas (3).

La Restauración, como epílogo de las turbulencias políticas del siglo XIX, consolidó un sistema político y jurídico que para el régimen local podemos caracterizarlo con estos tres rasgos:

1.- Uniformidad jurídica. - Es la etapa de los grandes Códigos y leyes generales que unifican ya definitivamente materias que todavía mantenían regímenes diferenciados. La legislación municipal desde la desaparición del Antiguo Régimen había sido uniformista. La

(3) Véase A. PoSADA: Evolución legislativa del Régimen Local en España, reed., Madrid, 1982; S. MARTIN-RETORTILLO y E. ARGULLOL: «Aproximación histórica al tema de la descentralización (1812-1931) s, en ob. col. Descentralización administrativa y organización polftica, dirigida por. el primero. Madrid, 1983; L. PAREJO ALFONSO: «La Región y la legislación histórica de Régimen Localo en ob. col. Las autonomias regionales, vol. I, Madrid, 1977, y L. MORELL OCAÑA: El Régimen Local español, Madrid, 1988. 
consolidación del uniformismo costará, por la existencia de distintas culturas, costumbres o nacionalidades dentro del Estado. Pero tan importante como lo anterior, y causa de mayores desajustes, era el tratamiento legislativo idéntico para municipios de distintas dimensiones en cuanto a población, y también de muy diferente actividad económica (ciudad populosa versus aldea que agrupa unas pocas familias, o municipio rural versus municipio industrial).

2. Subordinación político-administrativa del municipio.-Era una concepción ideológica ampliamente compartida. Además, técnicamente al municipio se le atribuían facultades, deberes, o funciones, pero en un sentido muy distinto de lo que hoy conocemos como competencias. La tutela se articulaba con un régimen amplio de autorizaciones, un sistema exhaustivo de suspensión de acuerdos y de remoción de cargos municipales. A ello hay que añadir que para aquellas atribuciones que, aunque exiguas, se consideraban como propias del municipio se establecía el oportuno recurso de alzada. Para el resto de materias no es que se careciera de recursos, sino que se actuaba bajo las órdenes directas del poder central y sus delegados. Por eso, como dice POSADA, la primera reforma que se orientara hacia la autonomía municipal debía establecer legalmente «la distinción reflexiva y ordenada de las funciones del Poder Central y las de los organismos locales que en todo el siglo XIX no se habían realizado" (4).

3. - Laxitud aplicativa de la legislación.-Las disposiciones de desarrollo e interpretativas de las leyes municipales no ofrecian soluciones técnicas y uniformes: en muchas ocasiones se dieron soluciones contradictorias. El poder central, bajo cuya égida se encontraba toda la Administración local, con tales disposiciones no trataba de crear un sistema congruente y sólido, sino más bien atender las necesidades políticas y coyunturales que se le planteaban. Así, la oportunidad política sustituía, a veces con grave quebranto, a la técnica, y aun a los elementales principios que en un Estado de Derecho han de observarse.

Había, además, problemas no resueltos como las municipalizaciones, que todavía era difícil realizar dada la existencia de un pudor ideológico liberal, o las elecciones a Ayuntamientos, como base sobre la que se organizaba todo un amañado sistema electoral general, o el problema político de las Regiones, cada día sentido con mayor intensidad, o la dispersión municipal que convertía a los Ayuntamientos en incapaces de prestar apenas algún servicio público, y que la previsión legal de las mancomunidades (arts. 74 y 80 Ley de 1877) no

(4) A. Posada, op. cit., p. 396. 
solucionó, ya que la voluntariedad de su constitución la convirtió en inutilizada (5).

El dato histórico de que el Régimen Foral se consolide en un Estado liberal de lenta consolidación, abrumado por las turbulencias políticas del siglo XIX, es fundamental para comprender sus dimensiones e importancia. No puede olvidarse que la Administración decimonónica se hallaba levemente estructurada, habiéndose apuntado la existencia de una Administración abstencionista por imperativos de la ideología liberal. Esta tesis ha sido cuestionada por algunos autores, pero de lo que no hay duda es que la escasez de medios materiales y personales de la Administración española durante el siglo pasado convierte en irrelevante el presupuesto ideológico: la intervención administrativa dependía fundamentalmente de los recursos y no de los límites formales que pudiesen estar presentes en la legislación, como ha quedado apuntado (6).

Navarra, a este respecto, va a jugar con una ventaja notable, ya que la recaudación de los impuestos queda reservada a la Diputación, viéndose obligada ésta a pagar, únicamente, un tanto alzado que ni siquiera era actualizado periódicamente. De este modo, el ámbito de intervención de la Administración foral guardaba más relación con el monto económico de lo recaudado que con los ambiguos perfiles dibujados por la Ley de 16 de agosto de 1841.

La Diputación asumió desde muy pronto la tarea de orientar política y jurídicamente las decisiones municipales. $Y$ para esta segunda misión apoyó la publicación de diversas recopilaciones normativas que determinaban la legislación municipal aplicable según un criterio anticentralista. Pueden citarse «El Manual para el Gobierno de los Ayuntamientos de Navarra", editado en 1846, y cuyo autor, J. YANGUAS Y MIRANDA era el Secretario de la Diputación; «EI Manual para la Administración Municipal de los pueblos de la provincia de Navarra», cofeccionado por los servicios técnicos de la Diputación en 1867; «El Novísimo Manual para la Administración municipal de los pueblos de la provincia de Navarra», publicado por la Diputación también en 1902, y la «Legislación administrativa de Navarra", elaborado por L. OROZ Y ZABALETA, también Secretario de la Diputación, en 1917. El examen de estos textos lleva a una conclusión muy diáfana: la normativa foral va ensanchando paulatinamente los ámbitos que regula, fruto de una interpretación globalmente favorable a la autonomía navarra. Adviértase que no se produce este ensanchamiento arrebatando parcelas de poder al

(5) Para consultas la legislación histórica resulta imprescindible la obra de T. R. FERnANDEZ Y J. A. Santamaria Pastor: Legislación administrativa española del siglo XIX, Madrid, 1977.

(6) Véase J. A. Santamaria Pastor: Fundamentos de Derecho administrativo, Madrid, 1988, pp. 124 y ss. 
Gobierno central, sino más bien reglamentando e interviniendo administrativamente espacios todavía vacíos.

En todo caso, el resultado interpretativo del ámbito autonómico contenido en la Ley de 1841 no es fruto de una tensión autonomíacentralismo que resultara a la postre siempre favorecedora para Navarra. En realidad, operaron factores contradictorios simultáneamente, unos a favor de la uniformidad y otros de la autonomía foral. Así, durante este período que ahora examinamos, el Derecho municipal común va penetrando en Navarra de forma gradual y confusa. Las causas que pueden alegarse son varias:

1. Prescripción legal de la Ley de 1841.-Esta ley reserva un espacio de autonomía para Navarra; pero no puede olvidarse que la mayoría de su articulado, como se expresó antes, establece un régimen exactamente igual al de las demás provincias.

2. - La pérdida de las Cortes de Navarra. - La Diputación asumió potestades heredadas de las otras instituciones del reino, pero no de las Cortes, por lo que se autoconsideró infradotada en potestad normativa. Idea falsa por cuanto en su área competencial, aunque fuese con reglamentos, podría establecer la normativa que tuviese por conveniente.

Las relaciones propias del Estado de Derecho entre las Cortes y el Gobierno se aplicaron, en ocasiones, retroactivamente por la Diputación. Así, el Reglamento de montes y arbolado el 30 de enero de 1851 comienza diciendo que su finalidad es procurar el más exacto cumplimiento de la Ley XXVI de arbolados y montes de las Cortes de Navarra de los años 1828 y 29. La Ley CX de las Cortes de 1817 y 18 conoce inicialmente dos reglamentos de desarrollo, el Reglamento de caminos vecinales aprobado el 30 de enero de 1851 y la Ordenanza para la conservación y policía de las carreteras de Navarra de 25 de enero de 1884. La Ley XXV de las Cortes de 1828 y 29 también se desarrolló por Circular de 20 de noviembre de 1872 (7).

Estos ejemplos manifiestan que esta institución del Antiguo Régimen tuvo proyección en el tiempo por más de una Diputación que no se consideró legitimada para reglamentar en contra de sus leyes. Ello motivó que en ocasiones se buscara la legislación general como más acorde a la realidad social, pero no fruto de la interpretación técnica de la Ley de 1841. Este erróneo inconveniente también fue paliado por el simple desconocimiento voluntario de las leyes de Cortes, pero nunca a través de una derogación expresa de las mismas por parte de la Diputación.

3.․ Mentalidad centralista de los gobernantes. -Desde el Poder central siempre se vio a Navarra como una provincia más, si acaso

(7) Todos estos textos están recopilados en la obra de L. Oroz y ZabaletA, op. cit. 
con alguna especialidad administrativa. No era la única con régimen especial, ni ello impedía que todos la considerasen parte de una nación que iba a obtener un progreso casi sin límites con la aplicación de una legislación uniforme y con mercados libres. Todo según las creencias más generalizadas de la época que siempre vieron en Francia el modelo a imitar.

Los gobernantes navarros participaron de esta nueva ideología centralista, por lo que las cotas de autonomía de Navarra, los decenios siguientes a 1841 , se conservaron en tanto que no se oponían a los fines perseguidos por el Gobierno central, con un respeto absoluto a la unidad de la nación, de su régimen político, y aun de los grandes hitos legislativos de su sistema jurídico.

4.- Traslación de contenidos del régimen general.-Dentro de las parcelas normativas de autonomía foral la Diputación imitó con profusión la legislación común. La falta de técnicos y de política propia en esa Administración pueden ser sus causas. La recepción del régimen común, aun en estos ámbitos, se produjo bien por el desconocimiento voluntario de la legislación propia y la aplicación directa de la común, o bien por la remisión a través de disposición de la Diputación a una ley o reglamento común.

Un ejemplo muy tardío pero claro es el Reglamento para el servicio de coches automóviles para las carreteras, aprobado por Real Decreto de 17 de septiembre de 1901. Pues bien, la Diputación, por Acuerdo de 10 de diciembre del mismo año, «acordó hacer suyo el citado Reglamento para que rija en la provincia". Partiendo del autorreconocimiento de su competencia, remite la regulación material a una norma general concreta; posteriormente se entenderá transferida, renunciada o inexistente la competencia (8).

La materia tributaria fue adquiriendo una progresiva complejidad que no fue resuelta sólo desde la Diputación, sino que, con mucha frecuencia, aspectos parciales de la misma como exenciones, apremios y trámites menores, se remitían a la legislación general. En fin, esta negligencia o imposibilidad de la Diputación para dictar reglamentos produce obviamente una penetración del derecho común en las parcelas reservadas a Navarra.

5.․ Necesidades prácticas. - La oposición entre legislación general y foral era resuelta a favor de la primera en la generalidad de los casos. Ello llevó a que particulares y Ayuntamientos aplicaran en ocasiones la legislación común, y no sólo por indicación de los Tribunales, sino en previsión de que pudieran intervenir ulteriormente anulando disposiciones amparadas en la legislación foral. OROZ $Y$ ZABALETA, comentando una sentencia centralista de 20 de octubre de 1896, dice lo siguiente:

(8) Véase el Manual... de 1867, op. cit., p. 804. 
«A nuestro parecer, constituye esta resolución un contrafuero, pero tendrán que atenerse a ella Ayuntamientos navarros, porque de lo contrario, no podrán prosperar las reclamaciones judiciales que interpongan" (9).

6.- Presiones del Gobierno central.-Los gobernadores civiles a veces enviaban circulares a los Ayuntamientos que, por afectar a materias propias del Régimen Foral, resultaban contradictorias con las de la Diputación. Estos conflictos se soportaron con distintas respuestas, llegándose incluso a la desobediencia civil. Pero había muchos casos en que la Administración central hacía ejecutar sus disposiciones, pues tenía medios para ello. OROZ Y ZABALETA comenta con cierta indignación, por ejemplo, el uso de la potestad de disolver los Ayuntamientos que tenía el Gobierno: "A pesar del régimen especial de Navarra, no han podido librarse algunos Ayuntamientos de caer en esta importante sanción, siendo lo más lamentable que la mayor parte de las veces que esto ha ocurrido ha sido motivado por el celo de las Corporaciones en la defensa de los intereses forales contra las intromisiones del Poder central» (10).

Hay, pues, una presión política importante canalizada a través del gobernador, pero no debe olvidarse que existe también una presión jurídica determinada por la prepotencia de las disposiciones del Poder central, y que actúa como complemento de la anterior.

Frente a estas vías de uniformización actuaron entrecruzadamente otras de sentido inverso y que permitieron consolidar un régimen administrativo especial en Navarra. Veamos algunas de las más importantes.

1. Miedo a nuevas guerras. - Las Leyes de Fueros se aprobaron como consecuencia de una guerra y esto va a marcar profundamente la evolución del régimen en todo momento. Navarra, a pesar de perder la I Guerra Carlista, siguió siendo mayoritariamente tradicionalista, e incluso fue potenciándose gradualmente esta tendencia. Para ANDRES GALLEGO, "que el temor a un rebrote de la lucha armada carlista en Navarra y las Vascongadas es constante en la documentación de los jefes políticos, incluso dos años después del abrazo de Vergara, en 1841; que los temores obedecían con frecuencia a hechos o a rumores sobre el porvenir de los fueros y que todo esto, en un Estado débil, no podía llevar a más que a la transigencia del Gobierno en aquello en lo que se veía amenazado» (11). Esto en los primeros años de andadura del régimen parece claro, pero mucho más tarde, en 1893, cuando el ministro de Hacienda Germán Gamazo

(9) L. Oroz y Zabaleta: op. cit., p. 306.

(10) L. Oroz y Zabaleta: op. cit., p. 527

(11) J. Andres y Gallego: Historia contemporánea de Navarra, Pamplona, 1982, p. 153 
pretendió una reforma fiscal que afectaba a Navarra recibió tal contestación popular que la prudencia política -temor a gravísimos desórdenes- determinó la continuidad del sistema de Convenio económico (12).

2. Penetración del pensamiento historicista.-El pensamiento historicista penetró en Navarra a finales del siglo XIX trayendo consigo proyectos políticos que veían el pasado con admiración. No parece probable que la doctrina de la Escuela histórica del Derecho encabezada por SAVIGNY entrase en una comunidad que ni siquiera tenía Universidad; sin embargo, puede apreciarse un resurgimiento del pensamiento tendente a potenciar la personalidad política de Navarra. El fuerismo y más adelante el nacionalismo son, sin duda, ejemplos de la penetración del pensamiento historicista y causa de que se extendiera a finales del siglo $X I X$ en toda Navarra una aspiración política común: la restauración foral. Es decir, la vuelta a las instituciones propias de autogobierno.

Esta voluntad política es bien visible en los gobernantes navarros que durante la Restauración protagonizaron abundantes episodios conflictivos con el Estado. El paulatino ensanchamiento de la actividad administrativa y de los recursos financieros y humanos de la Diputación contribuyeron a crear tensiones con el poder central.

La propia Diputación creó un órgano anejo a ella con apariencia de Cámara parlamentaria. Era el comienzo de una etapa reinstitucionalizadora de Navarra que trascendía los esquemas de la Administración local. Y ello en espera de un momento histórico oportuno que permitiera satisfacer en su plenitud la vocación restauradora. Esta Cámara representativa llamada Consejo Administrativo Foral se creó por Circular de 16 de julio de 1898; supone un primer jalón que va a tener una continuidad irregular, pero que, al menos en el Decreto-Ley de 1925, que más adelante se estudiará, se consolidará finalmente.

3.- Resultado favorable para Navarra de algunos conflictos con el Poder central. - La etapa de la Restauración, especialmente, fue pródiga en conflictos con el Poder central. En muchas ocasiones el compromiso político favorable a Navarra o el mero desconocimiento por parte de la Diputación de la normativa central que pretendía aplicarse abrió el ámbito competencial propio de la Ley de 1841. Tal es el caso del Servicio Médico municipal, los secretarios de Ayuntamiento, los contadores municipales e, incluso, la propia Desamortización, que fueron excepcionados, total o parcialmente, de la aplicación de la legislación general. Otras veces, sin embargo, la imposición de Madrid no pudo ser resistida.

En gran medida la interpretación de la Ley de 1841 estuvo en el campo de la libre presión de las fuerzas políticas. Visto el texto de la

(12) Véase J. I. del Burgo: op. cit., pp. 452 y ss. 
Ley de 1841 y las competencias que ejercía Navarra en 1925 podemos concluir que el resultado de la conflictividad arroja un saldo claramente favorable para Navarra.

Durante el siglo XIX la normativa municipal de Navarra fue casuista; también durante este siglo se consolida la subordinación jerárquica de los Ayuntamientos a la Diputación, fruto de la aplicación la legislación general que nunca consideró autónomas a los municipios.

\section{B) La revisión del Régimen local de Navarra en 1925}

El Estatuto Municipal de 8 de marzo de 1924 es considerado como una gran obra jurídica que apenas llegó a tener eficacia, pero que contenía en su texto novedades importantes para el Régimen local

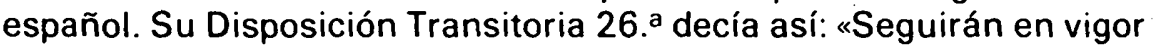
los regímenes especiales de las exacciones municipales de las Provincias Vascongadas y de Navarra" (13). Como puede apreciarse era una interpretación muy restrictiva de la Ley de 1841, a la que no derogaba.

Las Instituciones forales manifestaron su rechazo político a esta disposición, fundamentalmente porque no se había seguido el tradicional procedimiento paccionado de modificación del régimen y porque la autonomía municipal no era deseada en Navarra. Esta oposición política fue canalizada adecuadamente y tras las oportunas negociaciones se aprobó el Decreto-Ley de 4 de noviembre de 1925 intitulado «Bases para la aplicación del Estatuto Municipal en la provincia de Navarra».

Desde la perspectiva actual la técnica de remisión a los distintos órdenes normativos - común y foral- y el marco dispuesto como límite a respetar por los Reglamentos de Navarra adolecen de la falta de técnica, aunque parecen responder plenamente a los hábitos de aquel momento histórico. No se establece un sistema de distribución de competencias por listados, ni criterios que con nitidez señalen los campos de actuación foral o de Estado; tampoco hay mecanismos de coordinación o armonización entre ellos. Las conclusiones son, por consecuencia, fruto de un esfuerzo interpretativo y pueden resultar discutibles. Teniendo presentes estos datos, paso a exponer lo que, a mi juicio, son los contenidos del Decreto-Ley de 1925. con la intención de agruparlos sistemáticamente.

1. - Remisión al Régimen común.-El texto que analizamos hace una remisión al régimen general de algunos ámbitos administrativos,

(13) La legislación del siglo xx sobre Régimen Local puede verse en la obra de L. COSCULLUELA Montaner y E. Orduña Rebollo: Legis/ación sobre Administración Local (1900-1975), 3 tomos, Madrid, 1981 y 1983. 
en parte coincidentes con los que realizaba la Ley de 1841. Así, la elección y organización de los Ayuntamientos se regularían por la

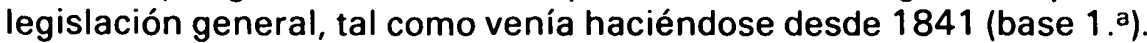
Todo el régimen de recursos también sería regulado por la legislación general: el de reposición previo al de alzada ante la Diputación, los recursos contencioso-administrativos, civiles, electorales y de índole gubernativa, así como en el recurso por abuso de poder (base 11). De igual modo el régimen de Carta y el referéndum (base 14).

2. Régimen especial directo para Navarra.-Hubo también apartados de directa aplicación no coincidentes con la legislación general. Uno de ellos es la regulación del Concejo abierto. Los negociadores navarros presionaron para que no se aplicara el Estatuto que lo establecía en los municipios de menos de 500 habitantes. Para Navarra se consiguió rebajar a 250, por lo que hubo de regularse un régimen especial para la formación de los Ayuntamientos con más de 250 y menos de 500 habitantes (base 2. ${ }^{\text {a) }}$. También se regula el certificado que los Ayuntamientos deben mandar a la Diputación con sus presupuestos, especificándose los contenidos del mismo (base 8. ${ }^{\text {a) }}$.

3. - Actualización de las Instituciones forales. - Las Juntas vecinales hasta el Decreto-Ley de 1925 tuvieron una confusa posibilidad de actuación, pues las Juntas creadas por la legislación general venían a coincidir en algunas competencias con aquéllas. Ahora se va a reconocer su existencia legal (base 2. ${ }^{\text {a) }}$. Igualmente puede deducirse de las bases alguna específica atribución de competencias remitida en todo caso a la normativa foral, como por ejemplo en la base $6 .^{\text {a }}$

Otra institución foral que se consolida es el Consejo Administrativo, al que se le da una composición que garantiza la mayoritaria presencia municipal, y al que se le atribuye potestad reglamentaria para todo lo referenie «a la administración y régimen municipal» (base 12).

$Y$, finalmente, se instituye un Tribunal Administrativo delegado de la Diputación para conocer de los recursos contra actos o disposiciones de los Ayuntamientos. La efectiva constitución del mismo se remitió a la voluntad manifestada por un número de Ayuntamientos que representara la mayoría de los habitantes de Navarra, las dos terceras partes de Ayuntamientos, la mayoría de habitantes por referéndum, o por mayoría de dos terceras partes del Consejo Administrativo (base 11).

4.- Consolidación del sistema relacional Navarra-Estado.-EI régimen de acuerdo previo propugnado por la doctrina foralista se cumplió en la elaboración del Decreto-Ley, pero no se conformó la Comisión con eso, sino que consiguió que constara en el texto la necesidad de nuevo acuerdo para modificar las bases (base 16). Es 
verdad que formalmente tal disposición no era vinculante para el posterior poder legislativo, pero políticamente no puede negarse su intención y efectos. Hay un inciso de impredecible alcance: se trata de la autorización para modificar las bases siempre que sea para ampliar la autonomía municipal (base 16). Según ello una Corporación local -la Diputación Foral- puede modificar un texto con rango de Ley.

5.9 Tutela preceptiva de la Diputación sobre los municipios. - Se utilizan tres intrumentos:

- Autorizaciones. Para enajenar o gravar los bienes municipales (base 3. a); para realizar obras y servicios cuyo coste, cubiertos preferentemente todos los gastos obligatorios del Ayuntamiento, no pueda satisfacer con los ingresos del año (base 5. ${ }^{a}$ ), y para aceptar préstamos, cuando no puedan ser reintegrados con los recursos sobrantes del año (base 6. ${ }^{\text {a). }}$.

- Aprobaciones. De presupuestos; pero si se cubren los servicios obligatorios, el presupuesto no tiene déficit y los tributos son reglamentarios no será necesaria la aprobación de la Diputación

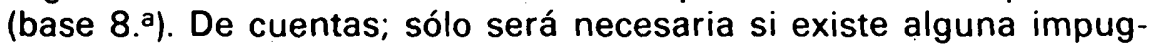
nación.

- Recursos administrativos. Serán los establecidos por la normativa foral. Pero la Diputación sólo puede realizar un control de legalidad, se excluye el de oportunidad (base 11).

6. - Competencias con la Diputación.-La Corporación Foral tiene un ámbito normativo más nítido que antes. Se extiende a las siguientes materias: bienes comunales (base 3. ${ }^{\text {\%) }}$, Funcionarios municipales (base 4. ${ }^{\text {a)}}$, Servicios y Obras municipales (base 5. ${ }^{\text {a)}}$, Haciendas locales (base 7. ${ }^{\text {a) }}$ y organización de las instituciones forales, tanto las Juntas Vecinales, como el Tribunal Administrativo y el Consejo Administrativo (base 2. ${ }^{a}, 11$ y 12). Estos últimos quedan como órganos de la propia Diputación, sin personalidad jurídica propia.

Puede apreciarse cómo en este texto legal se confirman jurídicamente competencias que de facto venían ejerciéndose y se ensancha el ámbito competencial de Navarra.

En desarrollo de tales competencias el Consejo Administrativo Foral aprobó un Reglamento que utilizó la técnica codificadora reuniendo en un amplio texto articulado todas las normas forales sobre municipios. Al objeto de que resultara un texto sistemáticamente correcto se produjeron reiteraciones de la legislación general en algunos casos. Dato éste que jugó un rol importante más tarde, ya que la legislación general se modificaba, pero el Reglamento de Administración Municipal de Navarra (RAMN) sólo lo hacía cuando lo 
acordaban las instituciones forales. De tal modo que el amplio espacio competencial atribuido por el Decreto-Ley de 1925 fue interpretado extensivamente por el RAMN, que, a su vez, en los apartados en que inicialmente reiteraba la legislación general, permitió la apertura a la normativa foral.

EI RAMN contenía detallada regulación sobre:

- Juntas Vecinales; segunda cámara municipal que aprobaba los Presupuestos, exacciones fiscales y todas las obras que tuviesen una cierta relevancia.

- Los Concejos; entes locales menores a los que se atribuyó recursos y competencias próximas a los de los Ayuntamientos.

- Deslinde de términos municipales si afectaba a montes o bienes comunales.

- Mancomunidades.

- Competencias, facultades y obligaciones de los Ayuntamientos, Concejos y autoridades municipales.

- Empleados municipales; secretarios de Ayuntamiento, sanitarios municipales (médicos, practicantes, comadronas, farmacéuticos y veterinarios), interventores, depositarios y demás empleados públicos.

- Montes y bienes comunales.

- La Hacienda Municipal.

- Contratos municipales.

- Responsabilidad y garantías de las autoridades y funcionarios.

- Procedimiento administrativo municipal.

Tras exponer este elenco de materias no parecerá exagerada la afirmación anterior de que se hizo una interpretación expansiva.

El primer texto sufrió muchas modificaciones a lo largo de su. dilatada vigencia para adaptarse a las nuevas circunstancias sociales y políticas. Tanto la legislación estatal como la jurisprudencia, en general, han respetado el ámbito competencial diseñado en el RAMN (14); después del Decreto-Ley de 1925 la conflictividad importante que existió entre Navarra y el Estado durante el siglo XIX y primer cuarto del siglo XX pugnando por sus competencias se redujo a cero. Las Instituciones forales regularon libremente el Régimen Local de Navarra sin que el Estado impugnase alguno de sus apartados. Así llegamos hasta la aprobación de la Constitución de 1978.

(14) Véanse, por ejemplo, la Disposición adicional undécima de la Ley municipal de 31 de octubre de 1935, la Base 68 de la Ley de Bases de Régimen Local de 17 de julio de 1945, los artículos 416 a 420 del ROF de 1952, el artículo 77 del Reglamento de Población de 1952, la Diposición adicional tercera del Reglamento de Haciendas Locales de 1952, la Disposición adicional tercera del Reglamento de Contratación de las Corporaciones Locales de 1953 y el artículo 209 de la LRL de 1955. 


\section{LA CONSTITUCION Y EL REGIMEN FORAL}

\section{A) Alcance de la Disposición adicional primera de la Constitución}

En la actualidad se halla superado el debate acerca de la virtualidad jurídica de la Constitución. El profesor GARCIA DE ENTERRIA, en uno de los estudios capitales de la literatura jurídica española de los últimos tiempos, ya apuntó tempranamente que todos los artículos de la Constitución «enuncian efectivas normas jurídicas», doctrina ratificada por el Tribunal Constitucional (15). Así, pues, todos y cada uno de los preceptos constitucionales tienen un contenido específico que vincula tanto a los poderes públicos en general como a los ciudadanos.

La Disposición adicional primera de la Constitución es un precepto más dentro de la misma sin que la ubicación sistemática pueda desvirtuar su carácter de portadora de un verdadero contenido normativo. Generalmente se ha pensado en Guipúzcoa y Vizcaya -provincias sin foralidad perceptible al punto de aprobarse la Constitución - al realizar la labor exegética de tal disposición. Es, no obstante, Navarra, el Territorio Foral con un ordenamiento propio vigente en 1978, la que, a mi juicio, ofrece un conjunto de elementos jurídicos que mejor sirven a una completa labor hermenéutica.

La presencia de la Disposición adicional primera en la Constitución plantea, para el caso de Navarra, un agudo problema interpretativo orientado, en un primer momento, a determinar el alcance $y$ contenido de los derechos históricos que ampara y respeta. En la práctica, ello supuso la vigencia revalidada del derecho foral -histórico- vigente al aprobarse la Norma suprema. Pero ahí, obviamente, no se agota su contenido.

Es preciso resaltar, ya de antemano, que la Disposición adicional primera es una norma excepcional. En la Constitución hay varios ejemplos de ello. Así, en el artículo 55 tiene un claro sentido de excepción al régimen general de los derechos fundamentales. $Y$ en el artículo 152 respecto del régimen general de acceso a la autonomía prevista en el artículo 148.2. De igual modo las Disposiciones adicional tercera y transitorias primera a quinta, tienen el mismo carácter. No es, pues, un caso insólito. Pero hay que añadir, es excepción, parcial como creemos, sólo al régimen autonómico general reconociéndose unos indeterminados "derechos históricos», a los, éstos sí, ciertos territorios forales. Y ello porque el contencioso que se pretendió solventar en el momento constituyente es la histórica reivindicación de poderes propios y amplios para las

(15) Véanse en su Curso de Derecho Administrativo, el epígrafe aLa Constitución como norma juridica», Madrid, 1983, p. 109. Véase también, por ejemplo, la STC 80/1982, de 20 de diciembre. 
instituciones forales. No se ha referido a derechos $y$ deberes fundametales, ni a la Corona, ni a las Cortes Generales, ni al Gobierno y las relaciones entre ambos, ni al Poder Judicial siquiera (16); únicamente se ha referido siempre, y así se contempla en la Disposición adicional primera, al reparto territorial del poder. Es decir, que la excepción resulta del Título VIII y, si acaso, del artículo 133.1, pero no de otros apartados.

No obstante, su redacción es confusa, y digo confusa por no decir contradictoria, ya que el tenor gramatical parece claro: se amparan y respetan los derechos históricos y se remite su actualización al iter estatutario, íntegramente. En tal supuesto, y al menos para el caso de Navarra, podían resultar contradictorios los párrafos 1 y 2 . Y es que puede discutirse ampliamente acerca de qué son los derechos históricos, pero una cosa no debe ofrecer lugar a dudas y es que el derecho foral vigente al aprobarse la Constitución, merced a este amparo y respeto que recibe de la misma, permanece con plena virtualidad jurídica. Se ha debatido si la disposición adicional primera pone en vigor normas derogadas en épocas anteriores, o si es una norma de remisión en blanco a ulteriores acuerdos políticos, pero lo que parece fuera de toda discusión es que el régimen administrativo especial de Navarra -Régimen Foral-, vigente desde la aparición del Estado unitario el siglo pasado, recibía un apoyo constitucional para su permanencia. No es de recibo la paradoja de que la disposición de amparo y respeto de los derechos históricos los deroga parcialmente por virtud de su párrafo segundo (17).

El desconocimiento del contenido del Régimen Foral de Navarra, proverbial fuera de sus lindes, y la manipulación política extrema de que es objeto dentro, hicieron ignorar el profundo contenido de la Disposición adicional primera. La verdad es que la escasa entidad del Régimen Foral hacía pensar que cualquier Comunidad Autónoma, por las vías ordinarias, lograría cotas muy superiores de autogobierno a la que Navarra conserva desde el final de la I Guerra Carlista. Pero, he aquí que el tiempo no ha dado la razón a este convencimiento generalizado $y$ hay algunas leyes que desarrollan y determinan lo básico reservado al Estạdo que necesitan, al igual que antes de la Constitución, de cláusulas especiales para salvaguardar competencias

(16) Ejemplifico con otros rótulos de títulos constitucionales, como puede verse.

(17) La bibliografía fundamental sobre la Disposición adicional primera de la Constitución puede cifrarse en la siguiente: B. CLAvero: El Código y el fuero, Madrid, 1982: «Del principio de salvedad Constitucional del Derecho histórico Vasco», en Primer Congreso de Derecho Vasco: La actualización del Derecho Civil, Oñati, 1984, pp. 171 y ss. y Fueros vascos. Historia en tiempo de Constitución. Barcelona, 1985. También todas las ponencias y comunicaciones nresentadas a las Jornadas de estudios sobre actualización de los derechos historicos vascos», Bilbao, 1986. Recientemente de I. M. DE LOJENDIO E IRURE: La Disposición Adicional primera... de la Constitución española, Oñati, 1988. De todos modos la obra clave desde una óptica jurídica sigue siendo la de T. R. Fernandez: Los derechos históricos de los territorios forales», Madrid, 1985. 
forales que sin quebranto soportó éste. Lo hoy determinado como básico en algunas áreas siempre ha sido regulado por Navarra. La virtualidad jurídica excepcional de la Disposición adicional primera se presenta así de forma evidente.

Mucho antes de que los desarrollos del 149.1 afectaran a competencias históricas, Navarra accedió a la autonomía por un procedimiento no regulado expresamente en la Constitución, y únicamente presente en el Real Decreto $121 / 79$, de 26 de enero. Tal procedimiento ha sido reconocido por el Tribunal Constitucional como apto para crear una Comunidad Autónoma y el apoyo constitucional que cita es la Disposición adicional primera.

El análisis no debe olvidar la existencia del párrafo segundo de la disposición. ¿Era necesario someter al marco estatutario los derechos históricos si ya lo estaban al constitucional?

Aparentemente es redundante. El pleno sometimiento estatutario convierte el precepto en superfluo y sin contenido jurídico - supuesto rechazado-. Y, además, para Navarra contradictorio con el amparo y respeto predicado en el párrafo anterior.

Felizmente desterrada la peligrosa interpretación que distringue dentro de la Constitución entre lo preceptivo y lo carente de virtualidad jurídica, hay que descubrir cuál es el alcance de la Disposición adicional primera y, a la luz de la legislación de desarrollo constitucional que la ha considerado un precepto más con verdadero contenido, descubrir sus perfiles normativos. Y la única interpretación posible es que marco constitucional y marco estatutario en la Disposición adicional primera no significan sometimiento a la totalidad del Título VIII. Ese marco para la actualización de los derechos históricos, a mi juicio es:

1. - Sometimiento absoluto a los preceptos constitucionales situados fuera del Cap. III del Título VIII, según se vio. No puede pasar desapercibido otro dato distinto de los apuntados antes y que interesa traer ahora aquí. El acceso a la autonomía es el único apartado constitucional de ejercicio potestativo por los poderes correspondientes. Absolutamente paralela es la previsión de la Disposición adicional primera, que, al entrecomar en el párrafo segundo la frase «en su caso", convierte en potestativo el derecho a la actualización de los derechos históricos. Por otro lado, el reconocimiento adicional de los mismos supone aceptar su imposible absorción total en el régimen ordinario de autonomías. La utilización de la expresión derechos históricos y la remisión al marco estatutario no puede impedir, por consiguiente, que la Disposición adicional primera contenga un régimen de autonomía parcialmente paralelo al ordinario del Título VIII, pero nada más.

2.- Procedimiento de acceso a la autonomía. Son muy variados; luego marco estatutario creo que no significa el que se pueda elegir 
entre uno u otro camino sometiéndose al rigor literal de cada uno de ellos. El marco estatutario es el principal: manifestación de la voluntad de autogobierno, texto negociado y aprobación por las Cortes mediante Ley Orgánica.

3. Reparto competencial. La asunción de competencias no es constitucionalmente uniforme; cabe la existencia de niveles competenciales distintos en cada Comunidad Autónoma. Aun en el supuesto de textos estatutarios agotadores -asumen todo lo que permite el artículo 149.1 - no puede decirse que el máximo techo competencial quede ahí determinado, ya que el artículo 150 permite las transferencias y delegaciaones anejas. El marco del reparto competencial del Título VIII es, pues, muy amplio y las competencias que puede ejercer una Comunidad Autónoma no tienen un límite preciso y determinado.

El marco estatutario al que se refiere la Disposición adicional primera no es el de esta o aquella competencia - el tema competencial no es, a mi juicio, el más importante del proceso regionalizadorsino, el principal. A tal efecto el Estatuto que actualice los derechos históricos tiene como marco el artículo 147, de cuya íntegra aplicación dependerá el que una norma pueda ser considerada como Estatuto de Autonomía o no. Así lo ha hecho el Amejoramiento.

Navarra en lo referente al reparto competencial no está sometida a todas las prescripciones del artículo 149.1, o mejor dicho, pues lo anterior requiere demasiadas matizaciones: no está sometida a cualquier desarrollo que de él se haga, sino únicamente al que sea compatible con las competencias históricas amparadas por la Constitución y actualizadas por el Amejoramiento.

La Disposición adicional primera, obsérvese, tiene una estructura normativa análoga a la Ley de 25 de octubre de 1839, pues ésta confirma los fueros y aquélla ampara y respeta los derechos históricos; una remite a una futura ley su adaptación a los mínimos de uniformidad que exigía la Constitución, y la otra con distinta expresión contiene idéntica propuesta. No debe seguir confundiéndose actualización de los derechos históricos con puesta en vigor de normas o instituciones del Antiguo Régimen, ya que la actualización en 1839 y en 1978 implica, simplemente, la adaptación del autogobierno foral a los parámetros convivenciales e institucionales establecidos en la Constitución. Ello significa necesariamente que el desarrollo normativo de la Disposición adicional primera admite distintas opciones políticas, diferentes respuestas legislativas; así, los «derechos históricos» - salvo el núcleo irreductible que protege la garantía institucional de los mismos-podrán dar lugar a regímenes forales sustancialmente distintos con el transcurso del tiempo en virtud de las sucesivas actualizaciones. 
La permanencia del derecho foral vigente al punto de aprobarse la Constitución encontraba un nuevo apoyo. A partir de ahora su asunción por la Norma Suprema lo convertía en un derecho con vitalidad renovada por cuanto se le reconoce su singularidad, se asume su contenido y se proyecta sobre el futuro su existencia.

Este reconocimiento genérico del derecho histórico, empero, no significa que quede relevado de someterse, como todo el derecho vigente anterior a la Constitución, a dos postulados básicos:

1. - El principio de interpretación de acuerdo con la Constitución. A partir de entonces resulta obvio que todo el sistema principal contenido en la misma afecta a nuestro derecho histórico, en tanto subordenamiento jurídico singular al que fundamenta. Así, las normas positivas contenidas en las Leyes de Fueros y en las disposiciones dictadas por los Organos forales, en lo sucesivo, se interpretarán de acuerdo con los principios, o preceptos en general, ubicados en la Norma Suprema.

2. Derogación de lo que se oponga a la Constitución. La Disposición derogatoria tercera deroga todo lo que se oponga a la Constitución vigente en el momento de ser aprobada. Sin embargo, antes de considerar derogada una disposición precedente, tal como señala el Tribunal Constitucional, hay que agotar los esfuerzos interpretativos para tratar de encontrar una lectura constitucional de la misma, evitando la siempre traumática tesitura de tener que considerarla derogada por su oposición frontal a la Constitución.

Conviene, para nuestro caso, observar que aquello que ha de entenderse derogado no es por su procedencia anterior, sobre la que no se entra, sino sobre su contenido inconstitucional. En definitiva, las Cortes Generales no podrían en la actualidad aprobar una norma con ese contenido. Parece claro, en consecuencia, que la Disposición adicional primera no contiene, en tanto cláusula excepcional, salvedad alguna del derecho foral, como mínimo, para aquello que incluso a las propias Cortes Generales les ha sido vedado porque resulta inconstitucional.

Es obvio que la Constitución tiene también un efecto derogatorio sobre el derecho foral, y esa derogación afecta a todo aquello que se le oponga radicalmente.

La aparente sencillez argumental que se presenta no resulta aceptada por la doctrina foralista tradicional (18) y por la práctica de aplicación del derecho foral. Así, por un lado, se siguieron aplicando normas palmariamente inconstitucionales bajo el pretexto de que el derecho foral habia sido respetado en su integridad, sin excepción

(18) Un ejemplo extremo se encuentra en F. SÁNCHEZ REBULLIDA y otros: El Derecho navarro tras el Amejoramiento, Pamplona, 1985. 
alguna; y en un proceso lento, que todavía no ha concluido, se han ido modificando las normas forales adecuándolas a los preceptos constitucionales, pero, sin reconocer que era una exigencia del Texto Fundamental, como una adaptación al momento presente impulsada por móviles de mera oprtunidad política. A ello hay que añadir un dato trascendental, y es que Navarra no ha accedido a la autonomía a través de alguno de los múltiples caminos que podía elegir en la Constitución, sino que se crea ex novo uno fundamentado en el derecho histórico amparado por la Disposición adicional primera.

Nos encontramos, por consecuencia, ante una comunidad política a la que la Constitución afectó de una manera muy singular. Se verá cómo de todo lo jurídicamente aplicado en el proceso constituyente y en el ulterior de adaptación se desprenden postulados interpretativos de enorme significado, que han de condicionar definitivamente la incardinación del derecho foral de Navarra en el ordenamiento constitucional del Estado.

Me propongo presentar a continuación todo este complejo tema que, a primera vista, podría parecer sencillo y superfluo, pero que un examen serio exige una especial atención por su particularidad. Y en ello voy a procurar huir del fácil recurso de reputar inconstitucional todo lo que no se ajuste a los criterios más rígidos y formalistas -en realidad carecería de sentido pues me alejaría de una realidad a la que, en cierto modo, su aplicación durante casi un decenio está convalidando-, y también siendo crítico con la doctrina foralista que en ocasiones, no es sino la cobertura ideológica de intereses políticos concretos, que no siempre respeta los principios y formas de nuestro ámbito de cultura jurídica, resultando, por tanto, de un carácter científico muy discutible (19).

Según lo expuesto el Régimen Local de Navarra, al margen del reparto competencial con el Estado que sí puede resultar singular, está sometido a todas las disposiciones constitucionales que directa o indirectamente le afecten. EI RAMN y normas complementarias han de ser interpretadas de acuerdo con la Constitución y considerarse derogado en lo irreductiblemente inconstitucional.

\section{B) El acceso de Navarra a la autonomía}

De acuerdo con los Decretos-Leyes 1 y 2/1978, de 4 de enero, el Real Decreto $121 / 1979$, de 26 de enero, que los desarrolla para Navarra, tenía por objeto el democratizar las instituciones navarras y determinar el Organo Foral competente para decidir la incorporación de Navarra al Consejo General Vasco. Las fuerzas políticas mayoritarias

(19) Véase P. LARÙmbe BiURrum: aReflexiones sobre las instituciones navarras», en ob. col. Euskal-Herria, Historia y Sociedad, San Sebastián, 1985. 
que, como es conocido, se hallaban divididas ante esta opción, y que a principios de 1978 parecían alineadas por la integración, al punto de aprobarse el Real Decreto 121/1979, es pensable que hubiesen resuelto ya abandonar tal postura. Y ello porque en la redacción del citado Real Decreto, fruto de un acuerdo político en el que formalmente figuraron como partes el Gobierno y la Diputación Foral, puede observarse cómo la decisión de mantener Navarra al margen del proceso estatutario común con los otros territorios históricos estaba tomada. Así, en el Preámbulo encontramos el siguiente párrafo:

«Es también función específica del Parlamento Foral proponer la reordenación de las competencias de las distintas instituciones forales navarras a la Diputación que resulte elegida, con el fin de que pueda formularse, en su caso, el correspondiente acuerdo con el Gobierno."

Se ve claramente cómo, además de desarrollar los Decretos-Leyes 1 y $2 / 1978$ y en correspondencia con la Disposición transitoria cuarta de la Constitución sobre la incorporación al Consejo General Vasco, se desarrolla el supuesto contrario, y aun se insta su aplicación. Más adelante, en el mismo Preámbulo, se vuelve a insistir en esta idea.

«El Gobierno y la Diputación estiman que el contenido de este Real Decreto constituye un «amejoramiento» o actualización del régimen foral de Navarra en su aspecto institucional, que habrá de ser completado con las propuestas que en su caso pueda formular en su día el Parlamento Foral y con aquellas otras competencias que, además de las actuales, pueda asumir la Diputación Foral de Navarra.»

Nuevamente insiste en la posibilidad de que se formule una propuesta para completar el esquema institucional y competencial de Navarra. Incluso en el texto dispositivo - art. 5.- - se comprueba claramente cómo el Real Decreto tiene entre sus objetivos otro distinto de la incorporación al Consejo General Vasco. Dice así el artículo 5.․:

«La Diputación Foral deberá someter a la aprobación del Parlamento Foral una propuesta de distribución de funciones, composición y forma de elección de los órganos de las instituciones forales. El texto que sobre la citada propuesta resulte definitivamente aprobado por el Parlamento Foral será negociado, en su caso, con el Gobierno por la Diputación Foral para pactar el correspondiente acuerdo.»

Es, por tanto, clara la llamada del Real Decreto a que la Diputación Foral negocie con el Gobierno una definitiva actualización del 
Régimen Foral descartando cualquier salida institucional común con los demás territorios históricos.

En efecto, tras la democratización de las instituciones la única iniciativa integracionista fue rechazada tempranamente y en fase de comisión. Por el contrario, el Parlamento inició rápidamente el desarrollo de la previsión del Real Decreto en su artículo 5.ㅇ

La Diputación en aplicación del mismo presentó al Parlamento dos tipos de Bases distintas para negociar con el Estado. Uno de Reintegración y Amejoramiento en el que se establecía un nuevo régimen de distribución de competencias entre el Estado y Navarra. Y el otro de Bases para la Reordenación Institucional en el cual se establecía un sistema orgánico y relacional del tipo parlamentario. Las Bases de Reintegración y Amejoramiento habían sido elaboradas según unos criterios de ortodoxia foralista. Contenian algunos postulados defendidos por el foralismo tradicional como, por ejemplo, la atribución residual de competencias a Navarra, la absoluta soberanía en materia fiscal, el alejamiento de los esquemas estatutarios en cuanto al sistema de relaciones entre el Estado y Navarra y el establecimiento de una Junta Arbitral que resolvería todas las cuestiones que se suscitaran entre el Estado y Navarra respecto de la aplicación de este nuevo pacto foral y que sustituiría, aparentemente, la intervención del Tribunal Constitucional, al menos en los conflictos de competencias.

El paso por el Parlamento cambió este proyecto convirtiéndolo en más moderado y ambiguo susceptible de permitir su acomodación a la figura constitucional de Estatuto de Autonomía.

Una vez aprobadas las Bases, tanto las de Reintegración y Amejoramiento como las de Reordenación Institucional, comenzaron las negociaciones con el Estado el 19 de diciembre de 1980 y concluyeron el 24 de febrero de 1982. Durante este período se firmaron los Pactos Autonómicos incorporándose, en aplicación de los mismos, varios de sus enunciados.

El texto aprobado por las Comisiones negociadoras fue sometido a votación de la Diputación el 9 de marzo de 1982 y del Parlamento el $15 \mathrm{del}$ mismo mes y año. Posteriormente el Consejo de Ministros lo envió a las Cortes Generales como proyecto de Ley Orgánica para su tramitación. Tanto en el Congreso como en el Senado se aprobó en lectura única, sin pasar previamente por la Comisión, según lo previsto en los artículos 150 y 129 de los respectivos Reglamentos, coincidiendo la publicacióún con el 141 aniversario de la Ley de Fueros de 1841, bajo la forma de Ley Orgánica 13/1982, de 10 de agosto, junto a otros tres estatutos de Autonomía.

La exposición de esta cronología puede completarse con el dato jurídico de que el Parlamento Foral rechazó iniciar el proceso de sometimiento a referéndum, según una moción presentada por los 
parlamentarios de Euskadiko Ezkerra; la argumentación de la mayoría que la rechazó se basaba en que Navarra no creaba un nuevo régimen sino que lo reformaba y, por tanto, no existía una variación de naturaleza suficiente para requerir ser plebiscitada. No cabe duda de que esta interpretación roza la inconstitucionalidad ya que, además de lo dispuesto en el Título VIII, el artítulo 23 establece el derecho de participación de los ciudadanos por el que deberán velar y fomentar los poderes públicos (art. 9.2) en un Estado democrático (art. 1. 1.9) en el que la soberanía reside en el pueblo (art. 1. 2.ㅇ). En todo caso es una decisión poco elogiable desde la perspectiva democrática.

Tanto los políticos como la doctrina foralista tradicional se manifestaron con profusión en la prensa acerca de la naturaleza jurídica de esta Ley Orgánica, entendiendo que se trataba de una reforma parcial del Régimen Foral - no actualización general-y por ello, en virtud de la Disposición adicional primera, p. 1, no necesitaba ser instrumentada a través de un Estatuto de Autonomía. Móviles políticos, sobre los que no es oportuno entrar, justificaban plenamente la defensa de estas posturas puesto que se había hecho ver en la singularidad no estatutaria de la autonomía navarra una diferencia en positivo que servía de bandera principalmente contra las posturas políticas que pretendían la incorporación de Navarra al proyecto común con los demás territorios históricos.

También se han publicado estudios en los que se ha razonado que el Amejoramiento no es un Estatuto de Autonomía ni Navarra una Comunidad Autónoma.

Para PULIDO QUECEDO nos encontramos en presencia de una vía singular y atípica. «Singular porque es la única Comunidad territorial española que ha utilizado la referida vía; atípica porque la actualización de su régimen con arreglo al principio de "Unidad constitucional" - concepto previsto en la ley de 1839 - se ha realizado no a través del cauce jurídico de un estatuto de autonomía, sino de una Ley de Reintegración y Amejoramiento.» En otro apartado dice: «la vía a la autonomía de Navarra distinta a la vía estatutaria tiene su razón de ser en los derechos históricos de la hoy Comunidad Foral de Navarra, y ese respeto histórico es el que determina el procedimiento singular que antes se ha expuesto" (20).

Para J. A. Asiain Ayala «los Estatutos de autonomía no eran un instrumento idóneo para aquellos territorios forales que no precisaban de un acceso al autogobierno, sino de una ampliación, perfeccionamiento o actualización parcial del régimen de autogobierno que anteriormente tenían reconocido. En el caso de Navarra - sigue este

(20) M. PuLLo Quecedo: «En torno a la Ley Orgánica de Reintegración y Amejoramiento del Régimen Foral de Navarra: Sistema de competencias», en RAP número 99, 1982, pp. 164 y 168. 
autor- esta ampliación, perfeccionamiento o actualización parcial de su aütogobierno debería llevarse a cabo, de conformidad con Tös principios propios del régimen foral, es decir, mediante el establecimiento de un pacto, convenio o acuerdo entre la Diputación Foral y el Gobierno de la Nación que posteriormente se incorporaría al ordenamiento jurídico a través de una norma de rango adecuado a su naturaleza» (21).

J. I. DEL BURGO, por su parte dice: «Navarra, tras el proceso de reintegración y Amejoramiento del Fuero, se parece a una Comunidad Autónoma, pero no es una Comunidad Autónoma. Navarra continúa siendo una "provincia". del Estado, si bien con régimen propio de autonomía, en virtud de su formalidad histórica, que la asemeja desde el punto de vista institucional a una Comunidad Autónoma» (22).

En un sentido análogo, pero más alejado de los parámetros del derecho autonómico, se pronuncia F. SALINAS QUIJADA (23). En definitiva, la doctrina foralista tradicional entiende que Navarra ha perfeccionado su antiguo Régimen Foral, pero no lo ha hecho a través de un Estatuto de Autonomía ni, por consecuencia, se ha convertido en Comunidad Autónoma.

La doctrina iuspublicista, en general, no había encontrado en la Disposición adicional primera de la Constitución procedimiento alguno de acceso a la autonomía. Al respecto, ningún estudio anterior a la aprobación del Amejoramiento se había detenido a explicar, siquiera aproximadamente, un contenido como el que finalmente se le ha venido a otorgar.

EI profesor MUÑOZ MACHADO, después de ser aprobado el Amejoramiento, dice que la Disposición adicional primera no deja dudas y declara con rotundidad que la actualización foral siempre ha de producirse en el marco de la Constitución y de los Estatutos de Autonomía. Y continúa: «Es, incluso, discutible que la citada disposición haya dispensado del procedimiento de acceso a la autonomía pero lo que puede afirmarse con rotundidad es que, desde luego, no ha excepcionado su instrumentación normativa, que debe ser el Estatuto de Autonomía” (24).

Para el profesor GARCIA DE ENTERRIA, «La foralidad podrá expresar, pues, determinados coritenidos competenciales y organizativos pero no constituye un título para excusar la aplicación de la Constitución o para negar a ésta su carácter de Ley superior en el territorio.» Más adelante señala: «La articulación Constitución-Estatutos sobre el

(21) J. A. Asiain Ayala: aLa Constitución y el Régimen Foral de Navarra», en Revista Jurídica de Navarra, número 1, 1986, p. 20.

(22) J. I. DEL BURGo: Introducción al estudio del Amejoramiento del Fuero. Pamplona, 1987. p. 199.

(23) En «xamen critico del Amejoramiento del Fuero de Navarra», en Revista Jurídica de Navarra, número 1, año 1986 , pp. 57 y ss.

(24) En Derecho público de las Comunidades Autónomas, vol. I, Madrid, 1982, p. 277. 
principio de primacía jerárquica de la primera es aplicable también incluso en el supuesto específico de nacionalidades y regiones que se amparan en los derechos históricos de los territorios forales; la cláusula de derechos históricos así lo impone al precisar que la actualización general de dicho régimen se llevará a cabo, en su caso, en el marco de la Constitución y de los Estatutos de autonomía, en fórmula que remite el artículo 147.2.d)’ (25).

Los profesores DE ESTEBAN y LOPEZ GUERRA se pronuncian en un sentido análogo: «este procedimiento denominado como amejoramiento del fuero navarro, comporta ciertas dudas sobre su constitucionalidad. En efecto, la Disposición adicionnal primera de la Constitución, tras señalar que ésta ampara y respeta los derechos históricos de los territorios forales, entre los que están indudablemente los de Navarra, manifiesta también que la actualización general de dicho régimen se llevaría a cabo, en su caso, en el marco de la Constitución y de los Estatutos de Autonomía. Lo que viene a significar que el amejoramiento del fuero navarro sólo ouede ser válido si se lleva a cabo mediante lo que señala el Título VIII de la norma fundamental» (26).

ENOCH ALBERTI, por su parte, ha escrito: «Se ha querido ver aún otra vía más, que, al amparo de la Disposición adicional primera, permitiría el acceso de los territorios forales históricos a la autonomía a través de un procesamiento extraestatutario. Esta interpretación, de muy dudosa constitucionalidad, ha fundamentado el procedimiento seguido por Navarra para constituirse en Comunidad Autónoma. En efecto, la Ley Orgánica de Reintegración y Amejoramiento del Régimen Foral de Navarra, de 10 de agosto de 1982, aun cuando en realidad constituye el Estatuto de Autonomía de Navarra, se elaboró y aprobó por un procedimiento singular y distinto a todos los previstos a tal efecto por la Constitución» (27).

TOMAS VILLARROYA también señala la dudosa regularidad del proceso seguido por Navarra para convertirse en Comunidad Autónoma. $Y$ concluye: «sin duda, se han seguido en otros momentos procedimientos singulares en el reconocimiento o renovación de los Fueros; pero la Constitución no los ha recogido y, por tanto, las únicas vías para que un territorio reciba la autonomía propia de las Comunidades Autónomas son las fijadas en aquélla. La Disposición adicional prevé el marco y los límites para la actualización de los derechos históricos; pero no puede servir de apoyo para la introducción

(25) En «La primacía normativa del Título VII de la Constitución», en REDA número 33, 1982 , pp. 278 y 279.

(26) J. oe Esteban y L. Lopez Guerra: Régimen constitucional español, vol. 2, Madrid, 1982. p. 364 .

(27) En la obra colectiva dirigida por E. AJA: El sistema jurfdico de las Comunidades Autónomas, Madrid, 1985, p. 98. 
de una nueva vía de acceso a la autonomía desconocida por la Constitución (28). Se pronuncia, pues, por la dudosa constitucionalidad del procedimiento seguido, al igual que hizo el diputado profesor SoLE TURA en el debate parlamentario del Amejoramiento (29).

No obstante la unaminidad doctrinal, en los Pactos autonómicos del 81 , se encuentra una frase que alentó el proceso iniciado. «En Navarra - dice- se procederá por la vía del amejoramiento del fuero y se respetarán las previsiones de la Constitución." Su ambigüedad permite defender varias posturas, entre ellas la que finalmente resultó aplicada.

En resumen, la doctrina ha manifestado su sorpresa y la dudosa constitucionalidad de la vía seguida por Navarra para acceder a la autonomía.

Tras varios años de andadura del nuevo Régimen Foral, calificar de inconstitucional algo que se tiene la certeza moral de que nunca va a ser declarado como tal, resulta conclusión sin futuro jurídico. La labor del jurista es, pues, aportar un posible encaje constitucional del procedimiento, aun a costa de situarse próximo a los límites de quebrar algunas fórmulas constitucionales. Así, el Tribunal Constitucional ha establecido que Navarra es una Comunidad Autónoma y el Amejoramiento un Estatuto de Autonomía. Ha procurado, sin duda, cohonestar los principios jurídicos con la realidad vivida si, al menos, ésta presentaba apariencia de juridicidad, y bajo este prisma posibilista ha aceptado la constitucionalidad de la vía del Amejoramiento. Se impone, por todo ello, al margen de valoraciones políticas, encajar el complejo sistema navarro en los flexibles esquemas de la Constitución.

La STC 16/84, de 6 de febrero, señala cómo en la Disposición adicional primera existe un procedimiento de acceso a la autonomía. En su fundamento jurídico tercero dice: «El hecho de que el acceso de Navarra a su actual régimen autonómico se haya llevado a cabo por una vía peculiar - mediante lo previsto en la Disposición adicional primera de la Constitución - y de que la denominación utilizada en la Ley Orgánica 13/1982, de 10 de agosto, de Reintegración y Amejoramiento del Régimen Foral de Navarra, para referirse a la Entidad Autónoma por ella regulada sea la de Comunidad Foral y no la de Comunidad Autónoma, no supone que no le sean aplicables esas disposiciones constitucionales, o que quede al margen de ellas." $Y$, tras señalar la flexibilidad formal de la Constitución, concluye: «La Comunidad Foral de Navarra se configura, pues, dentro de ese marco constitucional como una Comunidad Autónoma con denominación y

(28) En aProceso autonómico y observancia de la Constitución», en REDC número 15, 1982, p. 62 .

(29) Diario de Sesiones del Congreso de los Diputados número 55, de 30 junio de 1982. 
régimen específicos, que no excluyen su sometimiento, como las restantes Comunidades Autónomas, a los preceptos constitucionales que regulan el proceso autonómico. Ello se traduce en el mismo contenido material de la LORAFNA, que no sólo se configura según líneas idénticas a otros Estatutos, sino que contiene numerosas disposiciones que suponen el reconocimiento del sometimiento de la Comunidad Foral a las reglas generales que ordenan el proceso autonómico.»

El reconocimiento por el Tribunal Constitucional de que la Disposición adicional primera contiene un proceso de acceso a la autonomía nos lleva al siguiente razonamiento. En principio debe tratarse de un procedimiento cuyo fundamento se halle en tal disposición, y no en uno explicitado en ella, como es obvio, por su redacción. Este procedimiento debe inscribirse en un derecho histórico que es lo que ampara la Disposición adicional primera. Debe ser un derecho histórico actualizado, ya que al punto de aprobarse la Constitución navarra no podía contar entre sus normas con una de acceso a la autonomía por no caber en ninguno de los regímenes precedentes; y debe estar incluido en alguna norma, puesto que, como ha dicho el Tribunal Constitucional, la Disposición adicional primera no es un título autónomo del que puedan deducirse específicas competencias ni, a mi juicio, por tanto, tampoco procedimientos no específicados en alguna disposición (30).

Es decir, en la Disposición adicional primera cabe una fórmula de acceso a la autonomía previa la determinación de la misma en una actualización parcial - porque la general da como resultado un Estatuto de Autonomía y no un procedimiento de acceso a la autonomía- que debe ser lógicamente anterior, pues no se puede seguir un cauce que no esté previamente señalado.

Como se recordará, el procedimiento seguido es el establecido en el Real Decreto 121/1979 que, por tanto, tiene el carácter de una actualización parcial definidora de tal procedimiento. En base al fundamento histórico de la relación centenaria entre Navarra y el Estado mediante acuerdos políticos que luego se sustanciaban en normas jurídicas del rango que correspondiera, apoyado en la Disposición adicional primera, se ha permitido que el Real Decreto $121 / 1979$ se convirtiese en la norma que precisaba la vía de acceso a la autonomía de Navarra. Esta interpretación se me presenta como la única posible a sabiendas de que roza los límites de la constitucionalidad.

Por lo demás, parece deducirse de la jurisprudencia, tanto del Tribunal Supremo como del Tribunal Constitucional, la misma teoría.

(30) Véanse las sentencias del Tribunal Supremo $122 / 1984$, de 14 de diciembre, FJ $4 .^{\circ}$ y 76/88, de 26 de abril FJ 6.? 
El primero en una sentencia de 11 de octubre de 1983 ya califica al proceso vivido por la Diputación Foral entre los años 1979 y 1982 como el equivalente al desarrollo por los órganos preautonómicos (31). EI Tribunal Constitucional también en su sentencia $28 / 84$, de 26 de febrero, señala textualmente:

«Con posterioridad, la Ley Orgánica 13/1982, de 10 de agosto, de Reintegración y Amejoramiento del Régimen Foral de Navarra viene a reformar y modernizar el Régimen Foral - como señala su Preámbulo-, teniendo en cuenta lo dispuesto en la Disposición adicional primera, párrafo primero, de la Constitución, siguiendo el proceso de reintegración y amejoramiento reflejado en el Decreto anterior» - se refiere al Real Decreto 121/1979-. Por tanto, este Real Decreto contiene el proceso de acceso a la autonomía.

Igualmente en la STC 94/1985 de 29 de julio (FJ 2.ㅇ) dice que el Real Decreto citado inicia el proceso de reintegración y amejoramiento. Finalmente, ya se vio que el propio Real Decreto $121 / 1979$ señala en su Preámbulo que constituye una actualización de los derechos históricos. Por consiguiente, nos hallamos ante una vía a la autonomía establecida en el Real Decreto 121/1979 que formalmente se apoya en otras normas legales, pero que constituye una actualización parcial de los derechos históricos amparados por la Disposición adicional primera, y cuyo contenido es el establecimiento del procedimiento de acceso a la autonomía de Navarra, y tiene su fundamento histórico en la trayectoria de relaciones entre el Gobierno y la Diputación por la cual las modificaciones del Régimen Foral habían sido realizadas, en gran parte de los casos, previo acuerdo entre la Diputación y el Gobierno. Este procedimiento histórico fue elevado a norma en el Real Decreto 121/1979, el cual permitió a Navarra ascender a la autonomía constitucionalmente vigente, y convertirse en Comunidad Autónoma Foral, tal como lo han señalado las distintas Sentencias del Tribunal Constitucional que he mencionado.

La aceptación de las tesis foralistas tradicionales nos situarían en un marco jurídico incierto, pues, alejada Navarra del régimen general de las Comunidades Autónomas, sólo podría aplicarse la letra dél amejoramiento, en el cual, obviamente, no se reproduce todo lo previsto en el Título VIII para las Comunidades Autónomas. Excluida esta teoría por el Tribunal Constitucional, debemos contemplar las consecuencias de que Navarra sea Comunidad Autónoma, pero además titular de derechos históricos. En general, debe partirse, por

(31) Véase en la Colección Aranzadi, número 4876, de 1983. 
consiguiente, de que Navarra está sometida al régimen jurídico de las Comunidades Autónomas. Ello no obstante, es preciso aportar los siguientes datos complementarios:

1.- El Amejoramiento es un Estado equiparable a los amparados en el artículo 151 de la Constitución. Sus elementos comunes pueden resumirse en:

- Ser fruto de un pacto político en el que el procedimiento incluye un voto de ratificación por las Cortes.

- Tener una estructura institucional semejante: un Parlamento legislativo, un Gobierno de extracción parlamentaria y un Tribunal Superior de Justicia.

- Articulación competencial no limitada a lo previsto en el artículo 148 de la Constitución.

2. Régimen Foral queda equiparado a Régimen autonómico constitucional. A partir de este momento los derechos históricos actualizados $y$ positivados en el Amejoramiento constituyen el régimen de autonomía vigente en Navarra.

3. . El sistema de garantías es igual al de otras Comunidades Autónomas. De este modo, el Régimen Foral actualizado, por primera vez en la historia, se convierte en inmodificable unilateralmente, en virtud de lo que señala el artículo 71 del Amejoramiento, que tiene su fundamento en el artículo 137.3 de la Constitución.

4. - El procedimiento de reforma establecido en el artículo 71 no es ninguno de los previstos en el Título VIII, sino uno análogo al segundo para acceder a la autonomía de tal modo que el proceso de reforma estatutaria de Navarra, aún siguiendo los grandes trazos señalados por la Constitución, está fundamentado en la Disposición adicional primera, lo cual le permite alejarse levemente del resto de los procesos de reforma.

5.․ Las competencias asumidas en el Amejoramiento tienen una singularidad destacable. En efecto, asume competencias que antes no ejercía Navarra [(art. 39.1.b)] y además las que, según el artículo 150.1 y 2 de la Constitución, le atribuya, transfiera o delegue el Estado. Pero también conserva actualizadamente las competencias que ejercía al amparo de las Leyes de Fueros. La especificación que de las mismas se hace en el Amejoramiento apenas arroja luz sobre el contorno o límites de estas competencias. 
III. LAS COMPETENCIAS DE NAVARRA SOBRE REGIMEN LOCAL: EL ARTICULO 46 DEL AMEJORAMIENTO

\title{
A) El deslinde competencial
}

El artículo 46.1 del Amejoramiento dice:

\author{
«En materia de Administración local, corresponden a \\ Navarra:
}

a) Las facultades y competencias que actualmente ostenta, al amparo de lo establecido en la Ley Paccionada de 16 de agosto de 1841, en el Real Decreto-Ley Paccionado de 4 de noviembre de 1925 y disposiciones complementarias.

b) Las que, siendo compatibles con las anteriores, puedan corresponder a las Comunidades Autónomas o a las Provincias, conforme a la legislación básica del Estado.»

La revisión que el artículo 46.1.a) del Amejoramiento hace a la legislación foral para la determianción de las competencias sobre Administración local que corresponden a Navarra sitúa al operador jurídico ante una nueva singularidad cuya exégesis no encuentra instrumentos en el derecho autonómico. Los demás Estatutos de Autonomía hacen, con cierta frecuencia, remisiones a preceptos de la Constitución, del propio Estatuto o de alguna ley específica, pero nunca a una legislación ajena al desarrollo constitucional.

Para Navarra la asunción estatutaria de las competencias preconstitucionales era lógica en el Amejoramiento, y aun preceptiva, según la Disposición adicional primera de la Constitución. Se huyó, en este caso, de realizar una enumeración con terminología y articulación constitucionalizada y acorde con la estructura estatutaria, aceptando la, técnicamente criticable, remisión a las competencias que actualmente ostenta. Porque el mismo párrafo, tras citar las dos Leyes de Fueros con atribución de competencias para Navarra - Ley de 1841 y Decreto-Ley de 1925-, aun añade una expresión que contribuye a la indeterminabilidad del párrafo, pues la remisión no es sólo a sus textos, sino también a las disposiciones complementarias.

Si ya es difícil determinar cuál es el contenido jurídicamente en vigor de las Leyes citadas, si resulta comprometido traducir sus vetustas expresiones, pensadas en otro momento histórico y para un sistema político distinto, al lenguaje iuspublicista actual, la simultánea remisión a las disposiciones complementarias puede dar lugar a que este capítulo competencial quede abierto interna-corporis.

Procede, en primer lugar, dar respuesta a un problema elemental. Esto es, si las competencias sobre Administración local tienen naturaleza estatutaria en la medida en que se encuentran en la legislación remitida. 
Puede hablarse de remisión puesto que se indican en el artículo 46.1.a) los textos legales a los que hay que acudir para comprender su exacto contenido. De este modo la extensión de una de las competencias de Navarra, y de una de las determinaciones obligatorias de los Estatutos, se refiere a otros textos normativos, ya vigentes previamente.

Los Estatutos de Autonomía, y el Amejoramiento entre ellos, son, según el Tribunal Constitucional, elementos insustituibles para conocer las lindes de sus competencias. No en vano cita el artículo 147.1 entre sus contenidos obligatorios las competencias. El Tribunal Constitucional en su sentencia 18/82, de 4 de mayo (FJ 1.9) dice que «para determinar si una materia es de la competencia del Estado o de la Comunidad Autónoma, o si existe un régimen de concurrencia, resulta en principio decisorio, el texto del Estatuto de Autonomía de la Comunidad Autónoma, a través del cual se produce la asunción de competencias. Si el examen del Estatuto correspondiente revela que la materia de que se trata no está incluida en el mismo, no cabe duda que la competencia será estatal, pues así lo dice expresamente el artículo 149.3 de la Constitución».

Por su parte el fundamento jurídico 4 a) de la sentencia 76/1983, de 5 de agosto (caso LOAPA) señala: «Por lo que se refiere a la delimitación de competencias entre el Estado y las Comunidades Autónomas, de acuerdo con lo que determina el artículo 147.2d), de la Constitución, son los Estatutos de Autonomía las normas llamadas a fijar "las competencias asumidas dentro del marco establecido en la Constitución", articulándose así el sistema competencial mediante la Constitución y los Estatutos, en los que éstos ocupan una posición jerárquicamente subordinada a aquélla.» Por consecuencia, el Estatuto de Autonomía es el primero y más importante - tras la Constitucióninstrumento normativo delimitador de competencias.

Ahora bien, no es el único, puesto que la normativa básica, que puede ser de diferente extensión en el tiempo y que procede del Estado, por tratarse de un desarrollo constitucional del sistema de articulación de competencias es otro elemento que, si no atribuye competencias, sí dibuja sus exactos perfiles. Hay casos en que incluso los Estatutos remiten a una ley estatal expresamente para que sea ésta quien fije los contornos definitivos de una competencia. Tal es el caso del artículo 149.1.29. ${ }^{\text {a }}$ de la Constitución que somete la posible previsión estatutaria de crear Polícias autonómicas a lo que se disponga en una Ley Orgánica.

Así, el Estatuto de Cataluña, en su artículo 13.1, remite a esta Ley Orgánica todo lo que no esté especificado en el mismo sobre la Policía Autónoma. Igualmente el artículo 27.15 del Estatuto para Galicia señala que es competente la Comunidad Autónoma para 
crear su Policía Autónoma «de acuerdo con lo que disponga la Ley Orgánica prevista en el artículo 149.1.29. a de la Constituciónn.

Se observa, en consecuencia, que no es insólito el que leyes estatales extraestatutarias jueguen un papel relevante en la definitiva determinación del reparto competencial. De este modo puede verse cómo la remisión a las Leyes de Fueros encuentra un paralelismo con los ejemplos propuestos.

Un paso posterior en el análisis exige que nos detengamos a examinar la naturaleza de la remisión. Ha de partirse por afirmar que estamos ante lo que técnicamente se conoce por reenvío, es decir, el Amejoramiento se integra por el reenvío a las Leyes de Fueros.

Doctrinalmente se distinguen dos clases de reenvíos. El reenvío formal o no recepticio -es el más común-, «se produce siempre que un ordenamiento jurídico o una norma jurídica del propio ordenamiento, reenvía para su integración a otras normas u ordenamientos jurídicos sin hacerlos suyos" (32). La consecuencia inmediata es obvia: si se modifica la norma reenviada se repercute automáticamente en la reenviante. Son los casos examinados de los Estatutos catalán $y$ gallego.

El reenvío material o recepticio supone que «el autor de la norma reenviante quiere y asume el contenido del acto normativo al cual se reenvía como contenido de la propia norma reenviada pierde con ello su propia autonomía para convertirse en parte integrante del acto normativo reenviante, con lo cual el reenvío se convierte en un expediente técnico para incorporar contenidos normativos extraños» (33).

A mi juicio, el reenvío operado en el artículo 46.1.a) del Amejoramiento es material o recepticio. Por un lado, hay que considerar que fuera de los Estatutos $-y$ a salvo las leyes de transferencias y delegaciones, caso ante el que no nos encontramosno hay propiamente atribución de competencias, sino señalamiento de sus límites. Es decir, el Amejoramiento tiene que recibir como suyo el elenco de competencias que se derivan de las Leyes de Fueros. Por el otro, no es admisible que un determinado contenido competencial presente en el Amejoramiento esté sometido a un régimen jurídico distinto del propiamente estatutario. Lo contrario supondría que esta competencia no gozaría de la protección jurisdiccional del Tribunal Constitucional, ni estaría sometida al régimen de reforma estatutaria, como se sabe a salvo de la posible intervención unilateral de las Cortes Generales.

Lo previsto en el artículo 64.1.a) del Amejoramiento, en fin, es una asunción ad intra del contenido competencial de las Leyes de Fueros,

(32) J. A. Garcla-Trevijano Fos: Tratado de Derecho Administrativo, Madrid, 1968, Tomo I, p. 215 .

(33) Véase E. Garcia de Enterria y T. R. Fernandez: Curso..., cit., vol. I., pp. 229 y 230. 
una actualización estatutaria del derecho histórico a la competencia sobre Administración local. Funcionalmente el enunciado actúa como mera sustitución de tales Leyes. En lugar de reproducir sus textos - en parte derogados - se reenvía a los mismos la competencia, actuando las expresiones del Amejoramiento como mero nomen iuris o significante abreviado de su contenido, que sería el significado.

En conclusión, y como ya adelanté, el contenido de las normas reenviadas por el artículo 46.1 a) pasa a tener la naturaleza jurídica estatutaria del Amejoramiento y, por consecuencia, a gozar de todas las características inherentes a este tipo de leyes. Paso a destacar los caracteres que, según lo anterior, tiene el artículo 46.1a) del Amejoramiento.

1. Petrificación del contenido competencial.-Este carácter no es propio de los Estatutos de Autonomía. Es cierto que las expresiones jurídicas admiten una evolutiva interpretación, aunque permanezca inalterable su literabilidad, tal como señala el propio artículo 3.1. del Código Civil. Pero, sobre todo, las lindes precisas de una competencia serán fijadas por la legislación básica y moduladas, en su caso, por la normativa sobre las materias horizontales. Ello significa que en el tiempo los mismos títulos competenciales podrán experimentar ligeras variaciones en su contenido, según lo hagan las variables mencionadas.

En el Amejoramiento, por el contrario, la remisión a las competencias que ejercía en el momento de ser aprobado lleva consigo que queden petrificadas en sus contenidos, puesto que la legislación básica no será de aplicación en Navarra, según se vio, en lo que se oponga al derecho histórico.

La dificultad que entraña el reconducir a un listado las competencias a las que se refiere el artículo 46.1a), no quita valor a la afirmación anterior, puesto que la investigación y exégesis jurídica de tal precepto ha de referirse a un momento histórico concreto, en el cual regían unas normas que, en virtud del reenvío, y a los efectos competenciales, quedan revestidas de una cierta inmutabilidad. La flexibilidad que sobre la extensión de las competencias de las Comunidades Autónomas ordinarias puede operar una legislación básica de dimensiones variables no existe en este apartado del Amejoramiento. Navarra podrá ejercer las competencias sobre administración local pertenecientes a su derecho histórico introduciendo cuantas innovaciones normativas tenga por conveniente, pero las lindes con el régimen común permanecerán teóricamente inalterables.

2. Subordinación a la Constitución.-La especial naturaleza pactada de algunos Estatutos de Autonomía - singularmente del Amejoramiento-, y la ubicación que tienen en el sistema de fuentes 
no significa que se trate de normas constitucionales. Por no ser el nuestro un Estado federal, los Estatutos de Autonomía no son la Constitución propia de cada una de las Comunidades Autónomas, sino que por el contrario son normas derivadas de la Constitución, la cual es, a su vez de fruto una única soberanía formalmente reconocida. Este carácter derivado y no originario de los Estatutos implica su subordinación in totum a la Constitución y por consiguiente ninguna norma estatutaria puede oponerse a lo establecido en la Norma Suprema.

Y al mismo tiempo, todas su expresiones habrán de interpretarse de acuerdo con ésta. Así lo dice la STC 18/1982, de 4 de mayo: «EI Estatuto de Autonomía al igual que el resto del ordenamiento jurídico debe ser interpretado siempre de conformidad con la Constitución.» Una parte de esa Constitución es la Disposición adicional primera que, según vengo defendiendo, en lo que se refiere a competencias, supone la salvaguarda de las ejercidas históricamente por Navarra hasta la aprobación de la Constitución. Ello quiere decir, como expresé en el capítulo anterior, que no se aplicarán los desarrollos del Título VIII que se opongan a estos derechos históricos. No necesita, por la atención que dediqué entonces, mayor explicación este punto, pero cabe recordar que los principios constitucionales y sus instituciones jurídicas serán los instrumentos hermenéuticos a utilizar para la interpretación del Amejoramiento y sus desarrollos particularizados.

3. Indisponibilidad unilateral de su contenido. - Las competencias que ejercía Navarra hasta la aprobación de la Constitución no gozaban de un sistema de protección frente a la actividad legislativa del Estado equivalente a la que hoy tienen los Estatutos de Autonomía.

Es cierto que la Ley de 1839 establecía, como trámite previo a la elaboración de la que resultó ser Ley de 16 de agosto de 1841, la audiencia a las provincias. Es cierto, igualmente, que la base $16 .^{a} \mathrm{del}$ Decreto-ley de 1925 requería para su modificación de un procedimiento idéntico al seguido para su aprobación. Ahora bien, estas determinaciones legislativas no vinculaban, como es natural, al legislador futuro, que podría disponer libremente por no tener una norma superior como la Constitución que atara al legislativo en la inmodificabilidad unilateral de estos contenidos.

La Constitución de 1978, en su artículo 152.2, dispone que «una vez sancionados y promulgados los respectivos Estatutos solamente podrán ser modificados mediante los procedimientos en ellos establecidos». El artículo 147.3 previamente había establecido ya el mismo régimen: "La reforma de los Estatutos se ajustará al procedimiento establecido en los mismos...».

Estos artículos encuentran su aplicación en el artículo 71 del Amejoramiento que dice en el párrafo primero que el mismo es 
inmodificable unilateralmente $y$, a continuación, en el párrafo segundo, fija el régimen de pacto entre Navarra y el Estado preceptivo para la modificación, señalando finalmente, en el párrafo tercero, que continuará el régimen jurídico vigente si no se llega a tal acuerdo.

Por consiguiente, el contenido del artículo 46.1.a), y a los efectos del reenvío recepticio que aquí se examina, por tener naturaleza estatutaria, goza igualmente del privilegio de la inmodificabilidad unilateral que prescribe la Constitución y corrobora el Amejoramiento. Queda descartada, en definitiva, una hipotética modificación por el Estado de las Leyes de Fueros que afectase a los contenidos del Amejoramiento y en concreto a su artículo 46.1.a).

4. Superioridad jerárquica respecto de las demás fuentes de Derecho foral.-Ya la propia Constitución, en su artículo 147.1, determina que los Estatutos serán la norma institucional básica de cada Comunidad Autónoma. Ello significa, en palabras del profesor MUÑOZ MACHADO, que "las normas jurídicas dictadas a partir de las previsiones estatutarias se sitúan en posición de sometimiento jerárquico al Estatuto. Todas las normas autonómicas son de rango inferior al Estatuto sin perjuicio de que a su vez entre ellas aparezcan también jerarquizadas» (34).

Las competencias son, como se vio, de presencia obligatoria en los Estatutos, y su desarrollo está confiado a las distintas normas -leyes o reglamentos-que puedan dictar los órganos autonómicos. Así como es imaginable una ley autonómica que contradiga lo preceptuado en el Estatuto en una área como la institucional, resulta difícil pensar que una ley de desarrollo de una competencia sea contraria al mismo, ya que habitualmente no se hace sino enunciarlas con expresiones lacónicas. En cualquier caso, lo que resulta claro es que una ley foral, en nuestro caso, que estableciese algo contradictorio con el Amejoramiento resultaría inconstitucional. En concreto una ley foral que sobre Administración local se opusiera a lo previsto en la legislación de fueros asumida en el artículo 46.1.a) sería inconstitucional.

Al no existir un procedimiento de "antiestatutoriedad" ante un órgano ad hoc, es el Tribunal Constitucional quien resulta ser el órgano competente para conocer de esto. Bien es cierto que en nuestro sistema no hay posibilidad de recurso por oposición material, sino que se trata de una protección por motivos formales: la inconstitucionalidad de esa ley foral sería, no por oponerse directamente a la Constitución, sino por modificar el Amejoramiento sin seguir los cauces constitucionales y estatutariamente previstos.

Así, el contenido del reenvío se convierte, al haber asumido por una norma de naturaleza estatutaria, en parte de la norma cabecera

(34) En op. cit., vol. I, p. 293. 
del ordenamiento foral, en parte del vértice de la pirámide normativa de la autonomía navarra. En realidad, y si nos atenemos a su régimen de autonomía anterior a la Constitución, esta legislación de fueros ocupaba un lugar análogo al que hoy ocupan los Estatutos de Autonomía, puesto que se trataba de la normativa institucional del Régimen Foral y, al mismo tiempo, era la norma superior a la que tenían que subordinarse la totalidad de disposiciones aprobadas por cualesquiera de los órganos existentes en su complejo institucional. Funcionalmente, pues, su virtualidad no ha variado. No obstante, al estar dentro de un régimen constitucional radicalmente opuesto en sus principios de distribución territorial del poder y en su fuentes de derecho, las Leyes de Fueros, en su aspecto competencial al menos, son poseedoras de esta nueva naturaleza.

5. Protección jurisdiccional del título competencial.-Nuestro ordenamiento jurídico presta una protección especial y reforzada a la normativa estatutaria. Esta protección que tiene naturaleza jurisdiccional está encomendada a un órgano constitucional específico cual es el Tribunal Constitucional. Es este Alto Organo el que conoce de aquellas agresiones externas - también como se vio las internasque, procediendo del Estado o de otra Comunidad Autónoma, sufra el ordenamiento navarro.

Según se desprende del artículo 28.1 de la Ley Orgánica del Tribunal Constitucional éste no sólo juzga de acuerdo con la letra de la Constitución, sino que también tiene en cuenta otras leyes que delimitan competencias entre El Estado y las Comunidades Aunónomas, singularmente los Estatutos de Autonomía. A todo ello se le ha venido denominando "bloque de la constitucionalidad" y se convierte así en el parámetro de acuerdo con el cual tiene que sentenciar sobre la posible inconstitucionalidad de una norma.

Tanto la Constitución, que dedica el Título IX a este tema, como el artículo 36 del Amejoramiento, que señala: «En los casos y en la forma establecidos en las leyes, el Parlamento y la Diputación estarán legitimados para suscitar conflictos de competencia y para promover recursos de inconstitucionalidad", encuentran su aplicación en la LOTC.

Uno de los pilares del derecho histórico de Navarra, cual es el Régimen Local, se convierte por mor del Amejoramiento en parte de ese bloque de la constitucionalidad definitivamente, puesto que el inicial amparo y respeto de la Disposición adicional primera de la Constitución requería de la correspondiente actualización y definición para poder tener virtualidad jurídico-constitucional. $Y$ además la protección de su integridad puede residenciarse ante el más alto órgano jurisdiccional del Estado, el Tribunal Constitucional.

A la hora de concretar el espacio competencial de Navarra hay que acudir al elenco que se señaló como contenido del RAMN, pues ése es 
el ámbito histórico asumido por el Amejoramiento. La inseguridad jurídica, como es perceptible, es notable en este punto, ya que no existe una técnica precisa como la señalada en la Constitución para la relación legislación básica-legislación autonómica. En la práctica ello puede jugar un rol favorecedor de la expansión de la competencia sobre Régimen Local, dado que la propia Ley de Bases de Régimen Local establece que:

"La presente Ley regirá en Navarra en lo que no se oponga al régimen que para su Administración local establece el artículo 46 de la Ley Orgánica 13/1982, de 10 de agosto, de Reintegración y Amejoramiento del Régimen Foral de Navarra. A estos efectos, la normativa estatal que, de acuerdo con las Leyes citadas en el mencionado precepto, rige en Navarra, se entenderá modificada por las disposiciones contenidas en la presente Ley.»

En definitiva, va a ser la legislación sobre Régimen Local que apruebe el Parlamento de Navarra la que autodefinirá sus límites interpretando el artículo 46.1.a) del Amejoramiento, sin que sobre las competencias históricas la legislación básica enmarque o desplace a la foral.

En lo que se refiere a los ámbitos no históricos las competencias de Navarra se someten a la legislación básica como una Comunidad autónoma más. A este respecto, el artículo 46.1b) del Amejoramiento ensancha las competencias de Navarra, pero sometidas al régimen ordinario.

\section{B) El Tribunal Administrativo de Navarra}

El artículo 46.2 del Amejoramiento dice: «La Diputación Foral, sin perjuicio de la jurisdicción de los Tribunales de Justicia, ejercerá el control de legalidad y del interés general de las actuaciones de los Municipios, Concejos y Entidades Locales de Navarra de acuerdo con lo que disponga una ley foral.»

Esta previsión permite a la Diputación o Gobierno Foral la utilización de los resortes previstos con carácter general para defender la legalidad en la LBRL. No hay singularidad en este aspecto. Pero tras este párrafo se encuentra, sin duda, una habilitación para adaptar a los parámetros constitucionales el Tribunal Administrativo de Navarra (TAN).

Como se recordará, uno de los objetivos del Decreto-ley de 1925 era perpetuar el sistema de subordinación jerárquica de los Ayuntamientos a la Diputación propio del siglo XIX. De este modo los acuerdos de las Corporaciones Locales habían de recurrirse en alzada ante la Diputación con carácter previo a la interpretación del recurso contencioso-administrativo. En el propio Decreto-ley se previó la creación de un órgano desconcentrado funcionalmente de la Diputación 
para resolver estos recursos de alzada: el Tribunal Administrativo (TAN).

Los genéricos controles de legalidad que realizaba el TAN hasta la aprobación de la Ley Foral 2/86 partían de una concepción decimonónica de la Administración Pública en la que la subordinación jerárquica de los Ayuntamientos a las Diputaciones era normal. Otras legislaciones del siglo XX ya superaron estos esquemas, pero es la Constitución de 1978 la que destierra definitivamente de su orbe normativo la consideración de los Entes locales como menores de edad, en expresiva descripción del Tribunal Constitucional. EI TAN, por consiguiente, representaba un inconstitucional atentado a la autonomía municipal.

No es, sin embargo, esta apreciación jurídica la única que puede argüirse para-propugnar la desaparición o transformación institucional del TAN. En efecto, razones prácticas lo aconsejaban, ya que en toda impugnación de importancia era seguro que ulteriormente se daría el correspondiente recurso jurisdiccional. El principio de ejecutividad de los actos de las Administraciones Públicas y la excepcionalidad con que se aplica la suspensión de los mismos, convertía a este recurso de alzada ante el TAN en un instrumento dilatorio en perjuicio del administrado.

Este status de discriminación en negativo cuyo origen era el propio Régimen Foral no podía permanecer si pensamos que precisamente la razón de su existencia era el mantenimiento de un ordenamiento que respondiese mejor a las peculiaridades de Navarra y que, en ningún caso, podía seguir fundamentado en un prurito de singularidad, aunque fuese desventajosa.

La opción de la LBRL ante un supuesto que guardaba indudables analogías con el TAN, como era el caso de los Tribunales económicoadministrativos, hoy desaparecidos del ámbito del derecho municipal, ha sido la judicialización sin previa participación de entes administrativos intermedios. Esta era, sin duda, una de las posibles decisiones que el Parlamento de Navarra podía tomar. No fue así, sin embargo, y la Ley Foral $2 / 86$, decidió proceder a una transformación institucional del TAN que, respetando la autonomía local, situara al administrado en unas condiciones óptimas frente a la Administración local; decisión, en definitiva, de mantener una institución que no procedía de una sólida y antigua tradición foral, pues, como se recordará, apenas cuenta con dos decenios de existencia.

Es conocido que la bicentenaria lucha por el control de los actos del poder ha dado lugar a una constante evolución, en la que se aprecian dos constantes. La primera es la importación del modelo francés que, inicialmente adaptado y sometido a parámetros de desenvolvimiento propios, se separa más tarde definitivamente de él, 
sin que por eso pierda el carácter de ejemplar para la doctrina y los legisladores españoles.

Asi, el esquema del Conseil d'Etat de Napoleón se introduce en España con las leyes de 1845, dando lugar al Consejo Real. Ambos consejos tienen carácter consultivo con facultad de propuesta, ya que el Gobierno conserva la «jurisdicción retenida». Después en Francia se le reconoció la facultad de decisión propia - jurisdicción delegada-, y en España se procedió de forma análoga, pero iniciando una judicialización que culmina con la vigente Ley de 27 de diciembre de 1956. En efecto, con la LJ el control de los actos de las Administraciones Públicas queda sometido en exclusiva a la jurisdicción ordinaria, a jueces y magistrados pertenecientes a lo que la Constitución de 1978 denomina Poder Judicial (35).

La pregunta que podemos hacernos es si con la judicialización se acaba el proceso, o si la dinámica política y social está impulsando la apertura de un nuevo estadio evolutivo. La perfección técnica de la LJ no ha sido suficiente para dar al administrado en la jurisdicción contencioso-administrativa la eficaz garantía de sus derechos frente a la Administración. Como ha dicho J. A. SANTAMARIA PASTOR, «en el momento actual es forzoso reconocer, aunque nos duela, que la gran masa de ciudadanos no ve ni siente el contencioso como un instrumento efectivo de protección frente a las arbitrariedades de una Administración todopoderosa" (36).

Esta crisis sobre las que, por motivos obvios, no voy a entrar exige imaginativas respuestas que neutralicen la relativa inmunidad práctica en la que vive la Administración Pública, equiparable a la del siglo pasado, a pesar de la formal perfección técnica de sus instrumentos de control.

En atención a estas consideraciones pienso que la solución dada por la Ley Foral 2/1986 que convierte al viejo TAN en un órgano de utilización potestativa por el administrado, gratuito, rápido y al que podrá acudir sin necesidad de defensa letrada, un órgano que, si estima las pretensiones del administrado, suspenderá ordinariamente durante la ulterior tramitación del proceso contencioso-administrativo los efectos negativos del acto impugnado, es una respuesta criticable, sin duda, pero en su configuración elogiable en tanto que avanza experiencas del futuro al aceptar el reto de complementar las garantías del ciudadano frente a la Administración. El nuevo TAN conserva, pues, el nombre y algunos caracteres de su homónimo precedente; sin embargo, ha quedado perfectamente constitucionalizada su función como voy a tratar de exponer.

(35) Véase la obra del profesor Garcia de EnTERRiA: Revolución francesa y Administración contemporánea, Madrid, 1981.

(36) En aVeinticinco años de aplicación de la Ley Reguladora de la Jurisdicción contenciosoadministrativa: balance y perspectivas», en RAP número 95, 1981, p. 127. 
El fundamento estatutario de la existencia del TAN se halla en el artículo 46.2 del Amejoramiento. En él se reserva al Gobierno de Navarra el control de la legalidad de la actuación de los Entes locales. La judicialización de este tipo de control que ha operado la LBRL en el Régimen común no impide que pueda complementarse con otras vías respetuosas con la autonomía garantizada por la Constitución. Es por ello que, en desarrollo del artículo 46.2 del Amejoramiento, el Parlamento de Navarra ha dispuesto de un procedimiento preliminar al contencioso-adminitrativo para reforzar la posición del administrado frente a la Administración local.

Debe recordarse, en todo caso, que el precepto del Amejoramiento tiene su antecedente histórico en la Base 11. ${ }^{a}$ del Decreto-ley de 1925 que es asumido por el mismo artículo 46.1 a) expresamente. De forma complementaria puede citarse en el art. 49.1.a) que considera competencia histórica de Navarra la regulación de la composición, atribuciones, organización, funcionamiento y régimen jurídico de las Instituciones Forales, una de las cuales es, sin duda, el meritado TAN.

La Ley Foral 2/1986 que venimos comentando no hace una regulación orgánica del TAN, sino que presupone su existencia ratificando tácitamente una parte de la normativa preconstitucional que configura el proceso ante él, derogando expresamente algunos artículos [D. $\left.D^{a} a\right) b$ ] y sustituyendo la redacción por una nueva en dos de ellos (D. Ad. 3. ${ }^{\text {) }}$.

La Disposición final segunda prescribe que el Gobierno de Navarra dictará las disposiciones reglamentarias a que hace referencia el número 1 del artículo 14 - deber de información-y, en general, cuantas sean necesarias para la ejecución y desarrollo de esta Ley Foral. Pues bien, el Reglamento ejecutivo deroga expresamente el resto de artículos del RAMN que quedaban vigentes, incluidos el 680 y 681 , cuya nueva redacción procedía precisamente de la Ley que trataba de ejecutar.

Esta incorrección técnico-jurídica encuentra material compensación en la presencia del texto íntegro de los citados artículos en el Reglamento (art. 21). Es verdad que no se ha quebrado frontalmente el contenido de la regulación dispuesta por el Parlamento, pero no es menos cierto que se ha despreciado su voluntad de que el procedimiento ante él siga recogido en el código de administración municipal que es el RAMN. Por otro lado, el Gobierno de Navarra no está habilitado para derogar sus preceptos, ya que corresponde al Parlamento de Navarra ejercer las facultades que antes tuvo el Consejo Administrativo.

La parte organizativa del TAN está regulada en su Reglamento Orgánico, aprobado por Acuerdo de la Diputación de 29 de diciembre de 1964. En él se dispone que el Tribunal estará integrado por cuatro Vocales y un Secretario, los cuales quedan sometidos a un detallado 
régimen de abstenciones y recusaciones como corresponde a la misión que se les encomienda. Figura, igualmente, un régimen de incompatibilidades poco riguroso, el procedimiento de sustitución y las normas de funcionamiento interno de la actividad del Tribunal.

Es significativo, también, que la Diputación se reserva la posibilidad de encomendar a los miembros del Tribunal — no al Tribunal como tal- la realización de cuantos trabajos de orden jurídico cosidere oportunos. Finalmente, este Acuerdo dispone que el Tribunal remitirá copia de sus sentencias (sic) a la Diputación, la cual se reserva la inspección del mismo.

El régimen permanece sustancialmente inalterado; puede citarse como normativa que afecta a este apartado el Acuerdo de la Diputación de 20 de marzo de 1980, que dota al TAN de un Vicesecretario con funciones de Secretario (sic).

El Tribunal Administrativo es hoy un órgano especializado de la Administración Foral de la que forma parte integrado en su única personalidad jurídica.

No es un órgano que actúa propiamente por delegación del Gobierno, ya que no hay una transferencia revocable de una función, sino una atribución legal de determinadas funciones y competencias al propio Tribunal con exclusión de la participación de otros órganos o unidades administrativos.

El recurso de alzada frente a los actos y Acuerdos de los Entes locales interpuesto ante el TAN se configura así como instrumento de especial garantía para salvaguardar efectivamente los derechos de los administrados. Los abundantísimos conflictos con las Administraciones locales que no llegan a ser conocidos por la Jurisdicción contencioso-administrativa, dada la insignificancia de su repercusión económica, pero que sitúan al ciudadano en un status próximo a la indefensión, pueden encontrar aquí una respuesta adecuada.

Téngase presente que la inmensa mayoría de los Entes locales de Navarra carecen de infraestructura económica y administrativa que garantice adecuadamente la legalidad de sus decisiones. En ocasiones, por ello, el TAN actuará como un órgano especialmente cualificado técnicamente que exigirá de las Administraciones locales la corrección de las ilegalidades que se cometieron, las más de las veces por falta de un asesoramiento cualificado.

Por otro lado, no puede olvidarse que su carácter potestativo permitirá que quienes no deseen la dilación temporal que su intervención exige puedan acudir directamente a la oportuna vía jurisdiccional. Para el administrado se convierte en un órgano especialmente protector, ya que en el supuesto de ser desestimado su recurso dispondrá gratuitamente de una opinión jurídica singularmente cualificada que le hará recapacitar sobre la conveniencia de iniciar un proceso judicial. 
Para el supuesto de la estimación le permitirá, en el peor de los casos, acudir a la sede jurisdiccional en la cómoda posición de demandado que habitualmente tiene reservada la Administración. Y además con la ventaja de que entre tanto la decisión del TAN debe ser ejecutada, salvo que el Tribunal contencioso disponga lo contrario y, por tanto, la Administración se verá obligada a observar una diligencia procesal que hasta ahora no le beneficiaba. Para el administrado, en fin, un precioso resorte compensatorio de la fáctica situación de debilidad en la que se encuentra de ordinario frente a la Administración.

Pero también para los Tribunales Jurisdiccionales el funcionamiento del TAN ha de suponer un aligeramiento de su trabajo, sobre todo de estos pequeños asuntos - piénsese en los tributos locales-que van a encontrar vía más rápida y gratuita de solución en esta previa instancia administrativa.

Sobre su naturaleza administrativa poco puede polemizarse, ya que el TAN está incardinado en una Administración pública y tiene vedado, en consecuencia, realizar función jurisdiccional alguna. Es cierto que el procedimiento es contradictorio y dotado de unas garantías procesales que lo hacen semejante al jurisdiccional. Pero la naturaleza jurídica del recurso no depende de ello, sino del órgano que resuelve y de la virtualidad de su decisión; y en el caso del TAN su naturaleza es notoriamente administrativa.

No se me oculta las posibles objeciones que pueden hacérsele a este recurso de alzada desde la óptica de la garantía constitucional de la autonomía local. En efecto, la STC 4/1981, de 2 de febrero, ya señaló que la autonomía local era incompatible con los controles genéricos de legalidad. El control que realiza el TAN es, ciertamente, sólo de legalidad ya que, como señala el artículo 6. 2 de la Ley Foral $2 / 1986$, el recurso de alzada podrá fundarse en cualquier infracción del ordenamiento jurídico, incluso la desviación de poder.

La expresión del Tribunal Constitucional ha tenido sucesivas explicaciones que pueden argumentarse para suavizar su rotundidad. Sin embargo, prefiero fijarme en la interpretación más acabada de la jurisprudencia del TC en el plano de la autonomía local cual es el régimen de relaciones interadministrativas del LBRL. $Y$ ello porque esto resulta metodológicamente más adecuado, a mi juicio, que entresacar frases de las distintas sentencias del Tribunal Constitucional en apoyo de la legitimidad constitucional del TAN.

En primer lugar quiero partir de un dato constitucional que debe informar el proceso interpretativo: el artículo 24.1 que prohibe la indefensión de los ciudadanos.

En el ámbito que nos movemos, aquí y ahora, una fórmula como el TAN está plenamente orientada a garantizar ese fundamental derecho, en el caso de que el transcurso del tiempo legitime el hacer 
del TAN con la eficacia. Pues un régimen institucional de garantías para el ciudadano no se legitima por su purismo formalista, sino, sobre todo, por la efectividad de sus resultados. Así, el otro dato constitucional relevante para el caso es el carácter servicial que a toda Administración, y también, por tanto, a la local, atribuye el artículo 103.1. El ciudadano se justifica por sí mismo ante la Constitución; la Administración, por la efectividad de su servicio.

El control de legalidad que realiza el TAN no se produce de oficio, sino a instancia de interesado y para beneficio del mismo. Es decir, la Administración Foral no dispone para sí de un instrumento de tutela a su voluntad frente a las Administraciones locales como es el TAN, sino que éste actúa en interés de un particular. La Administración local cuyo acto es recurrido no sufre perjuicio alguno, dado que la interpretación del recurso no suspende su ejecución, ni puede disponerlo el TAN (art. 8.1 y 2 de la Ley). Esta imposibilidad de suspensión evita, a mi juicio, cualquier duda sobre su constitucionalidad.

La resolución del recurso si es desestimatoria en nada cuestiona la autonomía local, pues el administrado se encuentra con un status idéntico al inicial, pero ahora ante la Jurisdicción contenciosoadministrativa. Si la resolución es estimatoria el Ente local viene obligado a ejecutarla, revocando el acto sin necesidad de acudir a los trámites del 109 y 110 de la LPA.

Es análogo supuesto, y aquí traigo la comparación, al requerimento que puede hacer la Administración del Estado o de la Comunidad Autónoma según el artículo 65.1 de la LBRL. En efecto, en el caso de esta última Ley no viene obligada la Entidad local a atender el requerimiento.

Pero, ¿cuáles son las consecuencias de la diferencia de regímenes? La única determinante es que mientras en el régimen navarro la Administración tiene la postura de demandante en el ulterior proceso jurisdiccional, en el cómun sigue siendo demandada. Ello no es por consecuencia de un imperativo de la autonomía local, sino por virtud de las leyes que regulan el procedimiento contencioso-administrativo que perfectamente podian disponer lo contrario.

En definitiva, la actuación del TAN se sustancia en una inversión del status procesal de las partes ante el procedimiento jurisdiccional, y ello únicamente en el caso de la estimación del recurso. Sólo una postura extremadamente formalista podría concluir la inconstitucionalidad de tal intervención, sobre todo si se tiene en cuenta que tal régimen no trata de subordinar los Entes locales a la Administración Foral, sino únicamente de mejorar la devaluada situación del administrado frente a los Tribunales cuando litiga contra la Administración. No hay, pues, violación alguna de la Autonomía local, aunque su virtualidad práctica va a depender de la agilidad y acierto jurídico 
de las resoluciones del TAN, dado que si acoge los defectos del lento funcionar jurisdiccional, el carácter potestativo de su actuación lo relegará al ostracismo.

\section{C) La autonomia municipal en Navarra y en el régimen general}

El artículo 46.3 del Amejoramiento dice: «Los Municipios de Navarra gozarán, como mínimo, de la autonomía que, con carácter general, se reconozca a los demás Municipios de la Nación».

Puede pensarse que se trata de una remisión al régimen general de controles, pero es destacable que, tras el párrafo 2. que remite a una ley foral los controles de Navarra, en el siguiente se disponga lo contrario.

A mi juicio, el artículo 46.3 del Amejoramiento es una norma de carácter no estatutario, concretamente una norma programática. La doctrina ha puesto de manifiesto la existencia dentro de los Estatutos de Autonomía de preceptos no propiamente estatutarios, por cuanto exceden del contenido básico y típico encargado constitucionalmente a los Estatutos.

El profesor MUÑOZ MACHADO distingue varios supuestos y estudia, para finalizar, las normas programáticas contenidas en aquéllos entendiendo por tales las «que describen un proyecto o incorporan directivas para los órganos políticos de la Comunidad relativas a su actuación o al desarrollo del proceso autonómico, señalan fines o sientan principios en los que la actuación política deberá inspirarse (37). Ha sido generalizada la incorporación de estas normas a los Estatutos, apreciándose con notoriedad su presencia en el de Andalucía, que en su artículo 12 señala verdaderos objetivos políticos a perseguir en la Comunidad Autónoma; pleno empleo, reforma agraria, desarrollo industrial, etc.

En nuestro caso concreto no puede haber inconstitucionalidad puesto que no hay ninguna redefinición de las competencias sobre Administración local, sino «señalamiento de unos objetivos para la actuación autonómica».

Claro que esos objetivos deben ser perseguidos por el legislador foral. Sin embargo, «tales normas describen opciones legislativas que no tiene el Estatuto la función de fijar de forma definitiva, sino que están entregadas desde la Constitución al legislador ordinario, que actuará según resulte de la voluntad de las mayorias que integran en cada momento el órgano legislativo regional, sometido, por determinación constitucional, a las reglas del principio democrático que lleva de suyo la posibilidad de variación y cambio, la apertura continua a opciones políticas nuevas. La congelación de opciones políticas y

(37) En "Derecho mihlico...", op. cit., vol. II, pp. 299 y 302 
organizativas sólo se produce en el texto constitucional, pero no es función propia del legislador ordinario que en definitiva es quien aprueba el Estatuto».

La doctrina italiana ante estos supuestos niega la virtualidad vinculatoria de estas normas programáticas. «En nuestro caso - concluye el profesor MUÑOZ MACHADO-, resulta también preciso llegar a la misma conclusión, notando, además, de acuerdo con lo que se ha expuesto más atrás, las dificultades que en nuestro sistema plantearía el control de las leyes regionales contradictorias con tales disposiciones de principio, más aún, cuando su particular estructura normativa hace difícil determinar las contradicciones en que puedan incurrir leyes regionales posteriores» (38).

La cualificada opinión de MUÑOZ MACHADO evita otro comentario. No obstante, a mi juicio, el artículo 46:3 del Amejoramiento no resulta absolutamente vacuo. Como mínimo, puede deducirse que contiene un principio institucional para Régimen local de Navarra de homologación a la regulación general, en cuanto a la autonomía.

En todo caso, resulta técnicamente rechazable por los problemas interpretativos que acarrea, sobre todo cuando de lo que trata no es de aumentar el espacio decisional de Navarra, sino justamente de restringirlo a la voluntad del legislador estatal.

\section{ANTE LA NUEVA LEY FORAL DE ADMINISTRACION MUNICIPAL}

Una gran parte del RAMN ha sido adaptado ya a la Constitución a través de sucesivas modificaciones. La próxima Ley que va a ser debatida este año, habrá de sistematizar las reformas, afrontar las pendientes y regular las nuevas competencias que como Comunidad Autónoma le permite ejercer la LBRL (39).

Voy a destacar sistemáticamente algunos problemas políticoadministrativos que debe resolver, y para los que no tiene limitaciones de la legislación estatal.

1. La delimitación competencial.-Ya se ha examinado la dificultad para averiguar los límites de la legislación estatal y la foral en esta materia cuando la competencia es histórica. La nueva ley habrá de deslindar (ya que la LBRL no lo ha hecho) cuáles son los apartados que quedan exceptuados de sometimiento a la legislación

(38) En $\alpha$ Derecho público...m, op. cit., vol. II, p. 306.

(39) Véase La Administración Local de Navarra, ob. col., dirigida por M. Razouin LizarRaga y P. M. Larumbe Biurrium, Pamplona, 1987. Igualmente el primero ha escrito $\alpha$ El régimen especial de Navarra», en la ob. col. dirigida por S. Muñoz Machado: Tratado de Derecho Municipal, vol. I. Madrid, 1988, pp. 971 y ss 
básica y en qué términos, separándolos de los que sean legislación autonómica ordinaria.

Igualmente parece oportuno que se prevea un mecanismo de relación entre la legislación general y la foral no sometida a la $L B R L$ para que el operador jurídico en el futuro actúe con la seguridad que exige el artículo 9.3 de la Constitución. En la determinación de estos extremos es oportuno que intervenga la Junta de Cooperación Navarra-Estado para que la solución resulte operativa. La omisión de estos extremos hará que la técnica ordinaria de desplazamiento que opera la legislación básica sobre la autonómica se invierta en el caso de las competencias históricas, permitiendo que el legislativo navarro no se someta a la legislación básica y sin que este sistema de vinculación ordenamiento estatal-ordenamiento autonómico sea sustituido por otro que garantice una seguridad jurídica suficiente.

2. Racionalización de la estructura administrativa municipal. - En Navarra hay 204 Ayuntamientos simples (sin entes locales menores en su seno) y 62 compuestos (conformados por la agrupación de varios Concejos). En efecto, en Navarra hay 474 entes locales menores denominados Concejos que gozan de una autonomía similar a la de los propios municipios en virtud de la regulación del RAMN. Setecientas Entidades administrativas para aproximadamente medio millón de habitantes parece inapropiado. Hay que disminuir el número de municipios y ubicar a los Concejos en la posición institucional de entes locales menores que nunca debieron abandonar. Hay imperativos constitucionales - la autonomía sólo es posible en municipios de cierto poder presupuestario-, administrativos -eficacia administrativa sólo cabe donde hay efectivamente una Administración con medios personales y políticos-; la democracia sólo es posible si las autoridades deciden sobre problemas que no les afecten directamente.

Hay otra posición de dudosa constitucionalidad que es mantener la Administración Foral como prestadora ordinaria de la mayoría de servicios públicos y dejar reducida la actuación municipal a pequeñas tareas vecinales, preteriendo la función de cauce de participación política que tienen los Ayuntamientos.

3. Dignificación de la Función pública municipal. - En Navarra los Cuerpos Nacionales de Administración local no han prestado servicios en virtud del Decreto-Ley de 1925. Desgraciadamente el nombramiento de estos funcionario todavía depende exclusivamente de los Ayuntamientos que no vienen sometidos a programas de selección alguno. Hasta épocas bien recientes el nombramiento se hacía por votación de la Corporación - como el siglo pasado- pero resultando inamovibles.

La situación de los Cuerpos generales de Administración es similar: se proveen libremente tras una selección sin programa 
homologado $y$, por consiguiente con graves diferencias entre uno y otro Municipio.

Hay que reconducir, sin duda, este caos a extremos de racionalidad, homogeneizando las pruebas selectivas y permitiendo la movilidad horizontal y la promoción profesional. 